\title{
Water versus Wireless Coverage in Rural Mali: Links and Paradoxes
}

\author{
Pedro Martínez-Santos *, José Antonio Cerván, Beatriz Cano and Silvia Díaz-Alcaide
}

Departamento de Geodinámica, Facultad de Ciencias Geológicas, Universidad Complutense de Madrid, C/José Antonio Novais 12, 28040 Madrid, Spain; jacervaz@gmail.com (J.A.C.);

beatrizcanoarnaiz@gmail.com (B.C.); sdalcaide@gmail.com (S.D.-A.)

* Correspondence: pemartin@ucm.es; Tel.: +34-91-394-4863

Academic Editor: Richard Skeffington

Received: 20 March 2017; Accepted: 19 May 2017; Published: 26 May 2017

\begin{abstract}
Water and wireless coverage were evaluated in a rural commune of southern Mali. All improved water sources in the area were checked for operability, accessibility, and water quality, while wireless coverage was tested by means of smartphones, phone calls, and instant messaging applications. Theoretical water coverage exceeded $82 \%$ of the total village surface area, thus beating the national and sub-Saharan African averages, but dropped to just $39 \%$ when considering only serviceable and contamination-free sources. In contrast, wireless coverage exceeded $90 \%$. These outcomes highlight a triple paradox: (1) water from theoretically safe (i.e., improved) water sources is often unsafe to drink; (2) wireless access is better than water access even though water is essential for human survival and telecommunications are not; and (3) excellent Internet coverage does not help a large number of people, who lack the skills, devices, or need to access it. While telecommunications seem to be making inroads towards universal access faster than the water sector, a survey of water committees uncovered a hidden nexus between both resources, revealing that increased wireless access is actually contributing to underpin water coverage in a variety of ways.
\end{abstract}

Keywords: water access; wireless access; improved water sources; human rights; geographic information systems; Mali

\section{Introduction}

\subsection{Background}

The United Nations has recognized the importance of universal access to water and sanitation on various occasions. For instance, the Committee on Economic, Social and Cultural Rights declared that the human right to water is indispensable for leading a life of human dignity, and that water access is a prerequisite for the realization of other human rights [1]. Furthermore, Resolution 64/292 states that clean drinking water and sanitation are essential human rights. Thus, it calls upon states and international organizations "to provide financial resources, help capacity-building and technology transfer to help developing countries to provide safe, clean, accessible and affordable drinking water and sanitation for all" [2].

Yet, nearly two decades into the 21st century, water access remains a challenge for communities around the planet. According to official statistics, 700 million people lack access to improved water sources [3], a figure that is most likely an underestimate [4]. Moreover, $80 \%$ of the illnesses in low-income countries are linked to poor water and sanitation conditions, and one out of every five deaths under the age of five can be attributed to a waterborne disease [5]. Water-related illness and the need to fetch water for domestic purposes frequently cause children to miss out on school, particularly outside urban and peri-urban areas [6]. It is also known that many children in developing regions, 
particularly girls, drop out of school due to a variety of water and sanitation-related factors $[7,8]$. Thus, poor water access restricts opportunities for education and personal development and contributes to economic stagnation in the long run.

Rural regions trail behind urban areas in terms of water and sanitation services [3]. Take, for instance, the case of sub-Saharan Africa. About $87 \%$ of the urban population had access to improved water sources in 2015 , but only $56 \%$ of the rural population did. Progress in the sanitation sector is slower, amounting to $40 \%$ and $23 \%$, respectively $[9,10]$.

Water is an important business in many countries, particularly in the Western hemisphere, but not in rural sub-Saharan Africa. There are significant building, maintenance, and monitoring costs involved in supplying water to remote villages, but little money to be made. Large investments, together with low economic returns, inefficient organization, and corruption, are some of the main reasons why water utilities do not often reach rural areas [11]. The main driving force behind the development of water infrastructures has been the public sector, sometimes with the help of non-profit organizations.

Many rural water supply networks consist of relatively unsophisticated and unmonitored arrangements that seldom go beyond hand pumps or small systems of water towers and public standpipes. These have been fostered across the African continent based on the assumption that operating more complex and expensive schemes is unfeasible due to the irregular distribution of the population and the absence of support facilities and trained professionals, among other factors [12]. The generalized absence of maintenance strategies has often proven detrimental to the sustainability of infrastructures, no matter how simple these may have been $[13,14]$. This has done little to improve things in areas where population density is low, rural villages are often invisible in political terms, and economies are rarely vigorous.

Wireless telecommunications are perhaps the most important technological development of the contemporary era. In less than two decades, Internet connections and cell phones have changed the way human beings relate to each other, particularly in industrial societies. Both have become indispensable for granting a range of human rights, promoting freedom of expression and opinion, and accelerating economic development and human progress. As a result, the United Nations has also defined ensuring universal access to the Internet as a priority [15].

Internet penetration is growing rapidly across the world [16]. By the end of 2015 there were over three billion Internet users, the vast majority of whom lived in cities. Two-thirds of them came from low-income countries. Current estimates suggest that $3 \mathrm{G}$ mobile-broadband coverage has extended from $45 \%$ of the world population in 2011 to nearly $70 \%$ in 2015 . About one-third of households in the developing world currently have Internet access, a figure that soars to $80 \%$ in high-income countries [17]. Cell phone use is spreading even faster. In 1999, just 10\% of the African population had access to cell phones. Connectivity was almost exclusively restricted to the Mediterranean countries and South Africa. By 2008 approximately $60 \%$ of the population could get a signal, and the area under coverage had grown to over 11 million square kilometers [18]. Currently, two-thirds of the African population (over 1.1 billion people) have access to a cell phone, and it is projected that about $80 \%$ of the people will be connected within five years [17]. These are all inspiring figures, even if the literature points out that some issues, such as different digital divides or the regulatory debate, are yet to be resolved [19-22].

Wireless technologies have been widely embraced across sub-Saharan Africa [10]. This is particularly true of urban areas, although rural regions are gradually catching up. Safety is perhaps the single most important parameter controlling the adoption of cell phones by the population [23]. The observed desire for safety via mobile phone use is strongly driven by the extent of crime in a country, which, in turn, is closely related to poverty and inequality. Entertainment and information have also become important triggers for adoption. Relatively inexpensive, useful, and versatile, cell phones have become the personal computers of Africa. The number of connected cell phones surpassed the number of connected computers across the continent several years ago [24]. Market-driven reasons also explain why wireless telecommunications have become a blooming 
business $[17,25]$, as mobile telecommunications have proven extremely valuable in enhancing everyday commercial transactions [26,27]. Furthermore, emigration patterns have been found to fuel telecommunication use, as having family members abroad has been identified as a catalyst for Internet adoption [22]. These factors all go along with a determined push to enhance telecommunications at the national policy level, including the privatization of this sector in several countries $[27,28]$.

Internet use is slowly beginning to gain momentum. Coverage is still patchy and access is constrained by factors such as infrastructure, urbanization, basic and digital literacy, affordability, and access to a device. This means that usage remains mostly circumscribed to urban environments, where life standards are closer to industrial societies and there are better education opportunities. Rural villages are collateral beneficiaries, as network cells need to be spread across the territory to provide effective coverage in those areas where most of the population lives. It is true, however, that Internet access can only continue to grow, building on already-widespread social habits such as cell phone use.

\subsection{The Link between Water and Telecommunications in Developing Contexts}

Water and telecommunications are obviously very different resources. They present dissimilar historical evolutions, provision models, and cost structures. However, the increasing reliance of water-related decisions on telecommunications provides substantial ground for a joint appraisal. Moreover, the nexus is becoming increasingly clear in the literature. For instance, Adams and Zulu [29] explain that cell phones and android applications are used to underpin peri-urban water supplies in Malawi, while Wakeyo and Gardebroek [30] argue that wireless devices allow for the sale of irrigated crops at a reasonable price, thus fostering water harvesting practices among Ethiopian farmers. Mponela et al. [31] show that mobile phones can be a key determinant for the adoption of agricultural technologies among smallholder farmers in southern Africa, and Schnegg and Bollig [32] describe how cell phones support community-based water management during droughts in rural Namibia. In certain cases, the connection is so explicit that hand pumps for water extraction are used to charge cell phone batteries. This is viewed by some authors as an opportunity to fundraise in order to prevent water infrastructures from falling into disrepair [33].

Comparing access to very different services also provides a means to raise awareness about the living conditions in developing regions by highlighting access to the essential versus the unessential. Take, for instance, the United Nations' World Toilet Day, a global campaign whose aim was to provide access to basic sanitation and whose 2014 call to action was based on the claim that "more people own a cell phone than a toilet".

\subsection{Research Objectives}

Incipient links between water and telecommunications call for the development of synergies that may help in the pursuit of universal access to both services. Within this context, the research hypothesis behind this paper is two-fold:

(a) Research hypothesis 1: Wireless coverage in the study area is higher than drinking water coverage.

(b) Research hypothesis 2: Widespread wireless coverage may be contributing to enhanced access to improved water sources.

A GIS-based framework was proposed first so as to compare access to water and wireless telecommunications. This was used to establish the extent to which these resources are available to the population. Some of the main complexities of the coverage and access concepts are explored, framing the results within the regional context and its potential evolution. Outcomes are then explained in terms of their relevance to the daily life of people and extrapolated to rural African societies. Finally, the results from a survey of water committees are used to discuss the water and telecommunications nexus, describing how wireless technologies may be contributing to enhanced water access across the study area. 


\section{Study Area}

Field data was gathered across Djedougou, a rural commune located within the Koulikoro region, southern Mali (Figure 1). Djedougou spans a surface of $630 \mathrm{~km}^{2}$ and comprises 30 villages. According to the local 2015 census (Table 1), the population is approximately 36,000, with an average density of about 60 inhabitants per square kilometer. Djedougou ranks within the top $10 \%$ most populous rural communes in the country, and within the top 15\% in the Koulikoro region. Close to $99 \%$ of the population lives in the villages. Approximately one-sixth of the people are concentrated in the capital, Beleko-Soba, and its immediate surroundings.

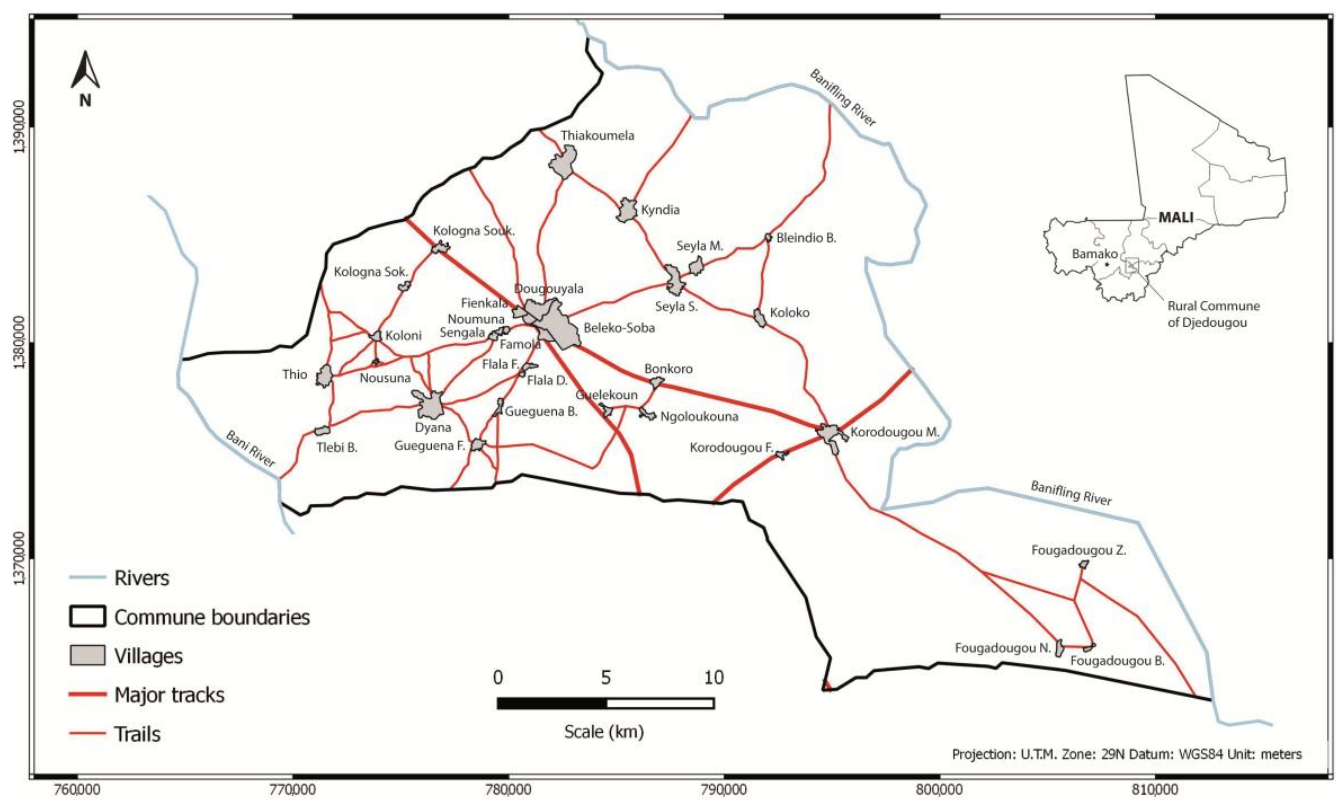

Figure 1. Geographical setting.

Table 1. Water coverage in Djedougou villages, expressed as percentage surface area within $500 \mathrm{~m}$ of an improved water source (i.e., a hand pump or standpipe).

\begin{tabular}{ccccccccc}
\hline Village & Population & Surface & $\begin{array}{c}\text { Theoretical } \\
\text { Water } \\
\text { Coverage }\end{array}$ & $\begin{array}{c}\text { Water Coverage } \\
\text { (Active } \\
\text { Sources) }\end{array}$ & $\begin{array}{c}\text { Water Coverage (Active } \\
\text { Uncontaminated } \\
\text { Sources) }\end{array}$ \\
\cline { 3 - 8 } & & $\mathbf{k m}^{\mathbf{2}}$ & $\mathbf{k m}^{\mathbf{2}}$ & $\mathbf{\%}$ & $\mathbf{k m}^{\mathbf{2}}$ & $\mathbf{\%}$ & $\mathbf{k m}^{\mathbf{2}}$ & $\mathbf{\%}$ \\
\hline Beleko Soba & 4687 & 2.31 & 1.32 & 57 & 1.32 & 57 & 1.02 & 44 \\
Bleindio B. & 455 & 0.07 & 0.07 & 100 & 0.07 & 100 & 0.00 & 0 \\
Bonkoro & 1233 & 0.19 & 0.19 & 100 & 0.19 & 100 & 0.18 & 93 \\
Sengala & 373 & 0.13 & 0.13 & 100 & 0.13 & 100 & 0.00 & 0 \\
Dyana M. & 1790 & 1.17 & 1.02 & 87 & 1.02 & 87 & 0.89 & 76 \\
Diawarala & 530 & 0.53 & 0.52 & 97 & 0.52 & 97 & 0.48 & 90 \\
Dougouyala & 640 & 0.80 & 0.77 & 97 & 0.70 & 88 & 0.52 & 65 \\
Famola & 159 & 0.09 & 0.09 & 100 & 0.09 & 100 & 0.00 & 0 \\
Fienkala & 363 & 0.24 & 0.24 & 100 & 0.24 & 100 & 0.24 & 99 \\
Flala D. & 219 & 0.05 & 0.05 & 100 & 0.05 & 100 & 0.05 & 98 \\
Flala F. & 309 & 0.14 & 0.14 & 100 & 0.14 & 100 & 0.14 & 100 \\
Fougad. B. & 665 & 0.08 & 0.08 & 100 & 0.08 & 100 & 0.08 & 100 \\
Fougad. N. & 1456 & 0.19 & 0.10 & 52 & 0.10 & 52 & 0.00 & 0 \\
Fougad. Z. & 672 & 0.09 & 0.09 & 100 & 0.09 & 100 & 0.00 & 0 \\
Gueguena B. & 469 & 0.16 & 0.16 & 99 & 0.16 & 99 & 0.00 & 0 \\
Gueguena F. & 665 & 0.25 & 0.25 & 100 & 0.25 & 100 & 0.25 & 100 \\
Guelekoun & 933 & 0.16 & 0.14 & 92 & 0.14 & 92 & 0.13 & 86 \\
Kyndia & 2884 & 0.67 & 0.64 & 96 & 0.64 & 96 & 0.00 & 0 \\
\hline
\end{tabular}


Table 1. Cont.

\begin{tabular}{ccccccccc}
\hline Village & Population & Surface & $\begin{array}{c}\text { Theoretical } \\
\text { Water } \\
\text { Coverage }\end{array}$ & $\begin{array}{c}\text { Water Coverage } \\
\text { Active } \\
\text { Sources) }\end{array}$ & $\begin{array}{c}\text { Water Coverage (Active } \\
\text { Uncontaminated } \\
\text { Sources) }\end{array}$ \\
\cline { 3 - 8 } & & $\mathbf{k m}^{\mathbf{2}}$ & $\mathbf{k m}^{\mathbf{2}}$ & $\mathbf{\%}$ & $\mathbf{k m}^{\mathbf{2}}$ & $\mathbf{\%}$ & $\mathbf{k m}^{\mathbf{2}}$ & $\mathbf{\%}$ \\
\hline Kologna & 961 & 0.40 & 0.40 & 100 & 0.40 & 100 & 0.00 & 0 \\
Koloko & 2112 & 0.27 & 0.27 & 100 & 0.27 & 100 & 0.27 & 100 \\
Koloni N. & 474 & 0.20 & 0.20 & 99 & 0.20 & 99 & 0.00 & 0 \\
Korod. F. & 707 & 0.11 & 0.11 & 100 & 0.11 & 100 & 0.00 & 0 \\
Korod. M. & 2470 & 0.79 & 0.61 & 78 & 0.37 & 47 & 0.00 & 0 \\
Ngolokouna & 659 & 0.18 & 0.18 & 100 & 0.18 & 100 & 0.00 & 0 \\
Noumouna & 962 & 0.09 & 0.09 & 100 & 0.09 & 100 & 0.00 & 0 \\
Seyla M. & 1046 & 0.35 & 0.31 & 88 & 0.31 & 88 & 0.00 & 0 \\
Seyla Soba & 2250 & 0.68 & 0.65 & 95 & 0.65 & 95 & 0.00 & 0 \\
Thio & 2077 & 0.52 & 0.52 & 100 & 0.38 & 73 & 0.00 & 0 \\
Thiak. Soba & 2992 & 1.10 & 0.47 & 43 & 0.47 & 43 & 0.47 & 43 \\
Tlebi B. & 680 & 0.20 & 0.20 & 100 & 0.20 & 100 & 0.00 & 0.0 \\
Total & 35,892 & 12.21 & 10.01 & 82 & 9.56 & 78 & 4.73 & 39 \\
\hline
\end{tabular}

The region presents a hot, semi-arid climate. Temperatures are high throughout the year, with the average standing at $26{ }^{\circ} \mathrm{C}$. Rainfall amounts to $800 \mathrm{~mm}$ /year. Rain concentrates in the wet season, which is short and irregular. During the dry season, lasting between October and June, there is barely any precipitation. Surface water courses run dry most of the time, except for the rivers Bani and Banifling, which make up the western and eastern boundaries of the commune, respectively.

Both rivers are too far away from most villages to be used for domestic supply. Groundwater provides a more reliable and accessible source, as the entire region is underlain by a shallow bedrock aquifer. The water table depth ranges between five and 15 meters at the end of the dry season, and remains closer to the surface, i.e., one to three meters, during the rainy months.

There is no running water in the vast majority of households. Most people obtain water to meet their everyday needs from public hand pumps or shallow excavated wells. Basic sanitation facilities, i.e., pit latrines, exist in many homes, particularly in larger villages. These are generally located in close proximity to domestic wells, thus posing a direct risk to shallow groundwater and human health [34].

The area features a predominantly rural landscape. Most people make a living out of agriculture or livestock. Cotton, rice, and millet are grown during the wet season, while onions and other orchard products are irrigated during the dry months. Livestock species include cattle, sheep, goats, and donkeys. There is some commercial activity in the larger villages, but not to the point of conveying a real urban impression. Cars are rare.

Cell phones and smartphones are commonly used by the population, particularly by the young. Most families own at least one cell phone. Mali's two main commercial providers have stands in some of the larger villages, where people recharge their accounts. Queues are frequent and prices are affordable.

\section{Materials and Methods}

\subsection{Conceptual Framework}

Comparative analyses may be used to evaluate the access of different populations to a given resource. This is generally achieved by defining a set of common indicators based on the available data [35]. GIS databases are frequently used for this purpose, the main reason being that access to resources tends to be constrained by spatial and temporal variables. The literature showcases multiple approaches to mapping the geographies of access to services, including transport [36,37], health care $[38,39]$, telecommunications $[28,40,41]$ or water [42-44]. 
This research banks of the assumption that the availability of water and telecommunications to the population can be quantified in comparable terms. Figure 2 presents the conceptual framework. Water availability is expressed in terms of improved water sources, and considers variables such as water quality, serviceability of infrastructure, affordability, or physical accessibility expressed as travel time and distance. On the other hand, the availability of wireless telecommunications is computed in terms of signal intensity and the ability to send or receive messages or calls. All these variables are spatially distributed and thus susceptible to being incorporated in a GIS database. Different GIS techniques are then used to express water and telecommunications coverage in terms of surface area, i.e., the percentage of village surface where access to these resources is readily available.

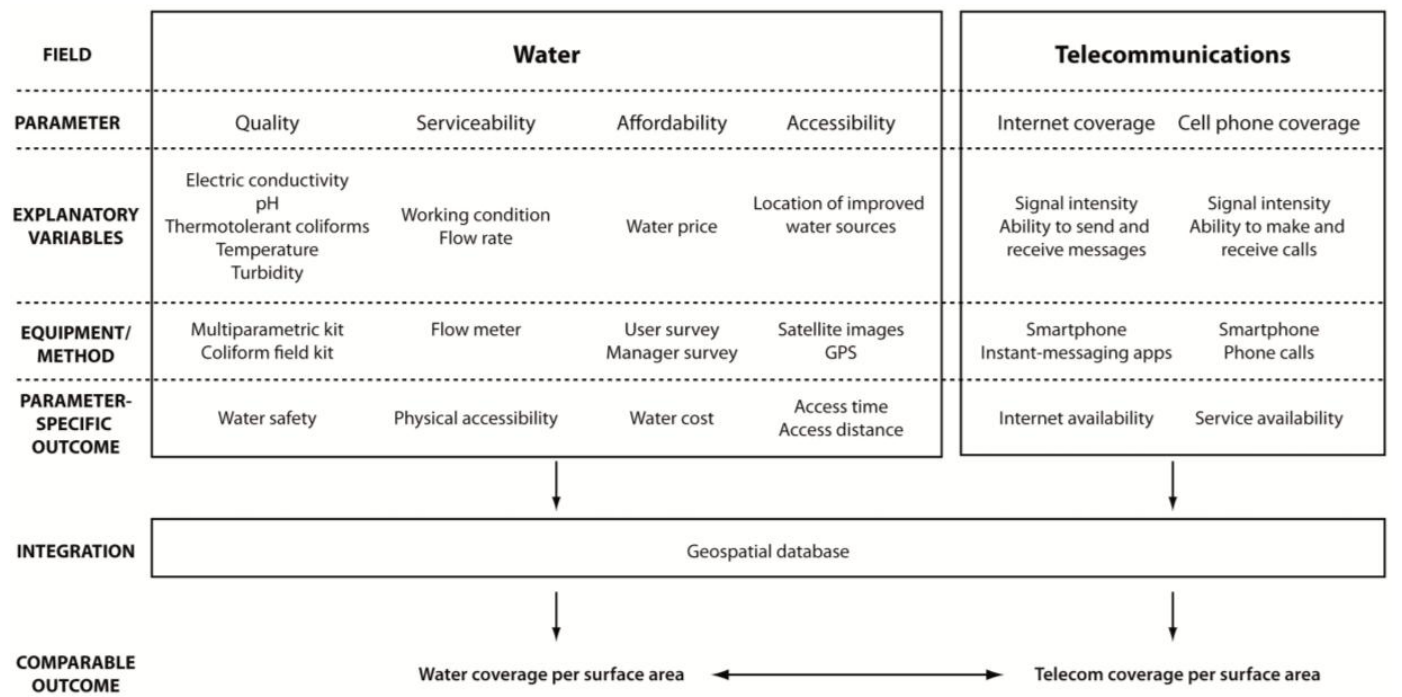

Figure 2. Conceptual framework.

\subsection{Field Survey}

\subsubsection{Water Data}

All improved water sources in the commune were visited over six consecutive days at the end of the 2016 dry season. An improved water source is defined as one that, by nature of its construction or through active intervention, is protected from outside contamination, in particular from contamination with fecal matter [45]. This definition encompasses household connections, public standpipes, boreholes, protected dug wells, protected springs, and rainwater collection. It leaves out unprotected wells and springs or surface waters. The concept of improved water sources is important because having access to these has officially been adopted by the Joint Monitoring Program as a proxy for having access to "safe drinking water" $[3,46]$.

The improved water sources include 60 hand pumps and 26 standpipes. All were geo-referenced doubly, first by means of a GPS and later by locating them by hand on a printed aerial photograph. Pumps and standpipes were all checked for flow rates and serviceability. Water samples were also gathered at each source to analyze water quality. These were tested on site for electric conductivity, total dissolved solids, temperature, and $\mathrm{pH}$ using a Hannah HI-98121 multiparametric device. Thermotolerant coliforms, free and total residual chlorine were also analyzed using an Oxfam-Delagua portable laboratory [47], while turbidity was measured by means of a standard field turbidimeter.

Indicator bacteria such as coliforms are frequently used to estimate the microbial quality of water. The existence of indicator bacteria in water is not necessarily dangerous to human health, but hints at the presence of pathogenic viruses, protozoa, and other parasites, which are more cumbersome to test and require more specific lab equipment. Themotolerant coliforms may be naturally present in the environment, but originate mostly in the digestive tract of warm-blooded 
animals. Among thermotolerant coliforms, Escherichia coli is a common indicator of fecal contamination, as it is universally present in large numbers in feces and does not grow in natural waters [48]. Although there are seasonal and spatial variations [49], there is a more or less broad consensus that, in most circumstances, populations of thermotolerant coliforms are composed predominantly of Escherichia coli [50-52]. Hence, thermotolerant coliforms as a whole are regarded as an acceptable indicator of fecal pollution [51].

Microbiological contamination is generally measured by identifying the quantity of colony forming units (CFU) per $100 \mathrm{~mL}$ of water. International standards cite $0 \mathrm{CFU} / 100 \mathrm{~mL}$ as the only acceptable coliform count for drinking purposes, though a concentration of 1 to $10 \mathrm{CFU}$ of Escherichia coli is sometimes considered tolerable [53].

As per the standard procedure, all collected samples were refrigerated, kept in the dark, and filtered prior to microbiological analyses. Cultures were prepared in petri dishes within $8 \mathrm{~h}$ of collection and incubated at a constant temperature of $44^{\circ} \mathrm{C}$ for $18 \mathrm{~h}$. Colony forming units were counted within $10 \mathrm{~min}$ of retrieval from the incubator. Coliform contents in excess of $50 \mathrm{CFU}$ were considered too numerous to count.

Turbidity is another relevant indicator of water quality. Turbidity is caused by suspended particles or colloidal matter that obstructs light. It is an important parameter because microorganisms such as bacteria, viruses, or protozoa are typically attached to particulates. Thus, the more turbid a water sample is, the more likely it is to bear some sort of pathogen. Turbidity is measured in nephelometric turbidity units (NTU) and is noticeable to the human eye above approximately 4 NTU. While turbidity should not exceed $1 \mathrm{NTU}$, monitoring low values can be a real challenge in remote regions. Hence, turbidity below 5 NTU is considered acceptable in cases such as the one at hand [51].

Finally, the presence of chlorine residual in drinking water provides a measure of potability. It indicates that chlorination treatment was sufficient to inactivate the bacteria and some viruses that cause diarrhea. It also means that the water is protected from contamination during storage. Boreholes were not expected to present any degree of chlorine residual, as they are seldom treated. Standpipes, subject to intermittent flow and dependent on water towers, were.

\subsubsection{Wireless Data}

Wireless data was collected by means of two smartphones of the kind that is available to the local population. A standard instant messaging application was used to send and receive messages while traveling around and within all 30 villages. A total of 315 readings were taken while traveling an approximate distance of $300 \mathrm{~km}$ along unpaved tracks and trails. This amounts to an average density of about one reading every two square kilometers. For logistic reasons, the spatial sample is skewed to population nuclei and to the road network, where most of the population spends most of the time. Messages were sent randomly from one smartphone to the other. The coordinates of the spot where each message was sent and received were recorded. The same strategy was used for cell phone coverage. Cell phone connectivity was tested by means of phone calls. Although it is acknowledged that there may be more sophisticated ways to do this, we also argue that the results provide sufficiently clear empirical evidence as to whether people can communicate through the wireless network.

In the case of phone calls, signal strength was noted as per a classic five-by-five scale, i.e., ranging from zero (no coverage) to four (excellent coverage) based on the screen display. Internet connectivity was assigned a zero value for no coverage, one for weak or intermittent coverage and two for good coverage.

An online search was carried out to check the results of the field survey against readily available Internet coverage data. Several webs were accessed, including the official sites of Mali's two mainstream operators. Online data were observed to differ strongly from field readings. Most notably, some of the websites showed no cell phone or Internet coverage at all in the area. Since field readings are empirically true, online references were assumed to be outdated. Online information was, however, useful to establish the location of telecommunication towers in the region. 


\subsection{GIS Database Development}

Field data were compiled into a GIS database. QGIS 2.12 Lyon was used for this purpose. QGIS is free, open-source software licensed under the GNU General Public License. High-resolution satellite images of the commune were downloaded from Google Earth using SASPlanet, which is also freeware and open source [54]. Shapefiles for Mali's administrative boundaries were obtained from the United Nations' Humanitarian Data Exchange website [55].

The database structure is relatively straightforward. Village contours were delineated as polygons according to satellite pictures in order to establish the spatial extent taken up by dwellings. Improved water sources were then geo-localized as a vector layer. Attributes for each water point include coordinates, type, elevation, working condition, flow rate, and water quality parameters. In turn, wireless readings were interpolated by means of geostatistical techniques to develop a telecommunications coverage map. QGIS' in-built functions were used for this purpose. Spatial interpolation follows the classic inverse distance weighted method. Curves and colors represent the intensity of the signal as recorded during fieldwork. Pixel resolutions of $1 \mathrm{~km} \times 1 \mathrm{~km}$ and $100 \mathrm{~m} \times 100 \mathrm{~m}$ were deemed suitable for regional and local analyses, respectively. Internet and water coverage were computed in terms of coverage per surface area.

There is still some debate as to what could be considered the maximum suitable distance from households to improved water sources. A one-kilometer one-way trip and a collection time of $30 \mathrm{~min}$, including queuing and filling, is a recurrent benchmark [50]. In the case at hand, the maximum distance was established by interviewing representatives from 120 households in Beleko-Soba. Results suggest that the vast majority of people living beyond $500 \mathrm{~m}$ away from an improved source will not use it (Figure 3). A 500-m buffer zone therefore was drawn around each water source. Buffers take into account the street layout, as different urban barriers prevent people from travelling in a straight line. The intersection between buffers and village polygons represents water coverage, understood as the total village surface within a one-kilometer round-trip of an improved water source.

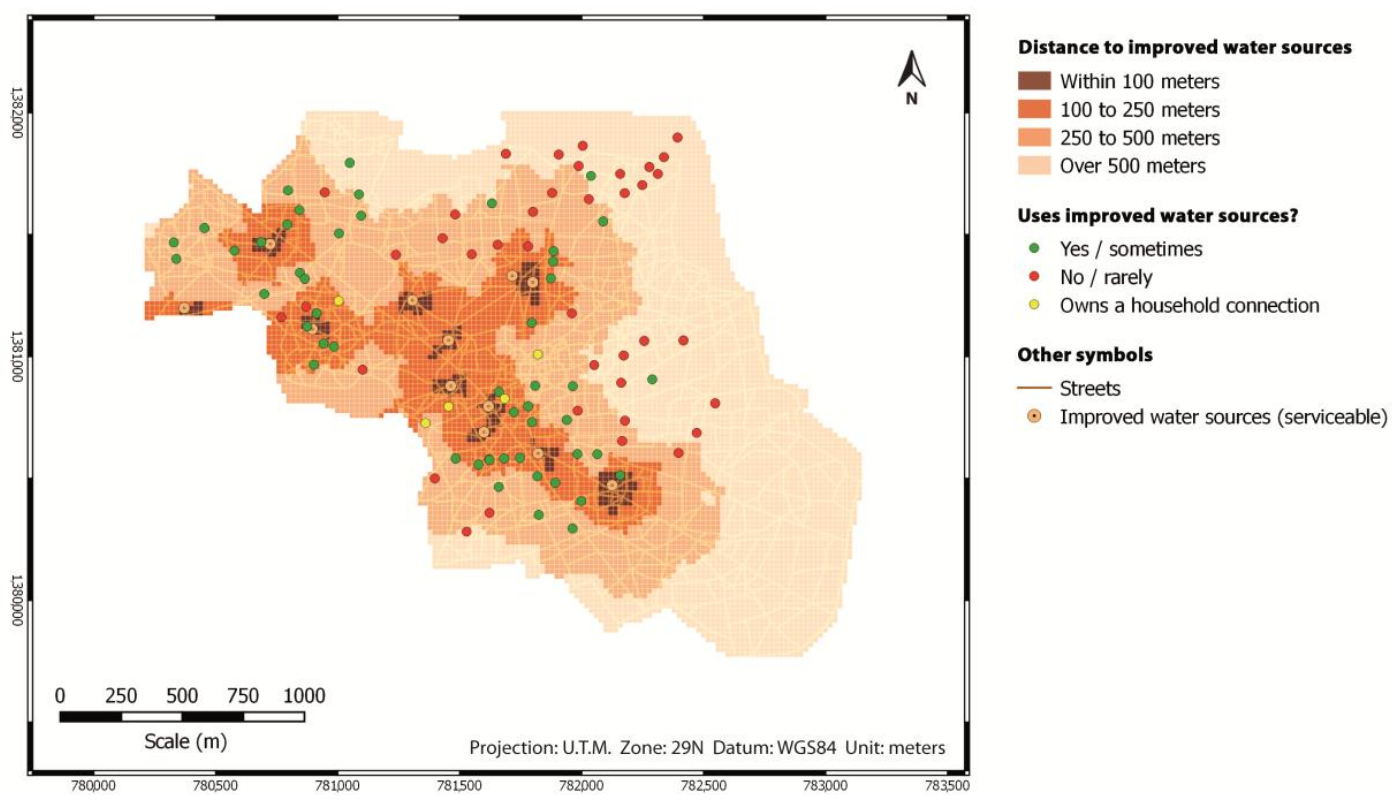

Figure 3. Access to improved water sources based on distance.

For practical purposes, adequate coverage not only means that pumps and standpipes work, but also that water quality is sufficient [56]. Hence, inactive water sources (i.e., broken pumps) were removed from the sample. So were those whose microbiological content exceeded drinking water standards. 
The intersection between water coverage buffers and village polygons was used to determine the share of the surface area with access to safe water. Households falling outside the buffer areas at the end of the process were considered to have insufficient coverage.

Aspects such as queuing times and costs are also important in some circumstances, particularly with large urban agglomerations [57]. However, these can be negligible in most rural villages. Queues seldom take place because the overall number of working sources is roughly appropriate for the size of the population and because a considerable number of people have access to excavated wells.

\subsection{Survey of Water Committees}

Water management in Mali falls under the competences of the Direction Generale de $l^{\prime}$ Hydraulique, which in turn belongs in the Ministère de l'Énergie et de l'Eau. As in several other African countries, community-based management of rural supplies is a core element of national water policy. Rural water supply is thus decentralized. Infrastructures are generally built through investments from of national and/or regional governments, as well as from NGOs. Municipalities have responsibility for ensuring that rural water supplies remain serviceable. This is ideally achieved by supporting communities directly or by arranging for other actors to do so. However, the supporting activities and mechanisms are not clearly defined [58].

In practice, daily operations are conducted by local water boards, termed "local water committees." The fundamental role of water committees is to ensure the long-term serviceability of improved water sources. Water committees decide on user fees and collect payments, generally for maintenance purposes. They are also expected to promote education in the fields of health and sanitation. However, water committees have limited capacity to act due to their voluntary nature (in most cases) and to the absence of strong institutional arrangements.

Fifteen members of local water committees were interviewed for the purpose of exploring the nexus between water and wireless access. Brief semi-structured interviews were conducted in all cases. Questionnaires included two sections. The first one dealt with water infrastructures as a whole. This included items on (a) the state of the infrastructures; (b) the level of service; (c) the three most important aspects that keep water infrastructure operational; and (d) the three most important aspects that need to be improved. The second part of the questionnaire referred specifically to the link between water and telecommunications. More specifically, committee members were asked (e) whether they owned a cell phone; (f) whether they had an Internet connection; (g) whether they ever used cell phones for committee-related tasks; and (h) whether they thought access to cell phones contributed to fulfil their roles as members of the committee (and, if so, how). In the case of members who do not speak French, interviews were conducted with the help of a local translator.

\section{Results}

\subsection{Water Coverage}

Villages span a joint area of $12.2 \mathrm{~km}^{2}$. Approximately $82 \%$ of the urbanized layout falls within $500 \mathrm{~m}$ of an improved water source. Assuming a uniform population density, this would imply a theoretical water coverage in excess of the national rural and total averages $(64 \%$ and $77 \%$, respectively). Coverage ranges widely, from practically $100 \%$ in some of the more compact villages to less than $50 \%$ in the more spread-out ones (Table 1). There are, however, some important precautions. For instance, out of the 86 water sources, 24 were found to be inactive due to different malfunctions. These include five hand-pumps and 19 standpipes. Once these are removed from the sample, the average water coverage per surface area is reduced to $78 \%$.

Table 2 shows some of the main water quality results. Only 15 out of the 62 active water sources tested negative for thermotolerant coliforms, while another 23 presented coliform counts below $10 \mathrm{CFU}$. Nine rendered coliform contents in excess of $50 \mathrm{CFU}$, including several too-numerous-to-count samples. Nineteen random samples were analyzed twice so as to check the accuracy of the process. A correlation 
coefficient $\mathrm{R}^{2}=0.91$ was obtained. This suggests that the results are reliable enough for practical purposes. Only four samples presented values in excess of 5 NTU for turbidity. All rendered zero residual chlorine.

Table 2. Water quality results in public water sources. Community of Djedougou, southern Mali.

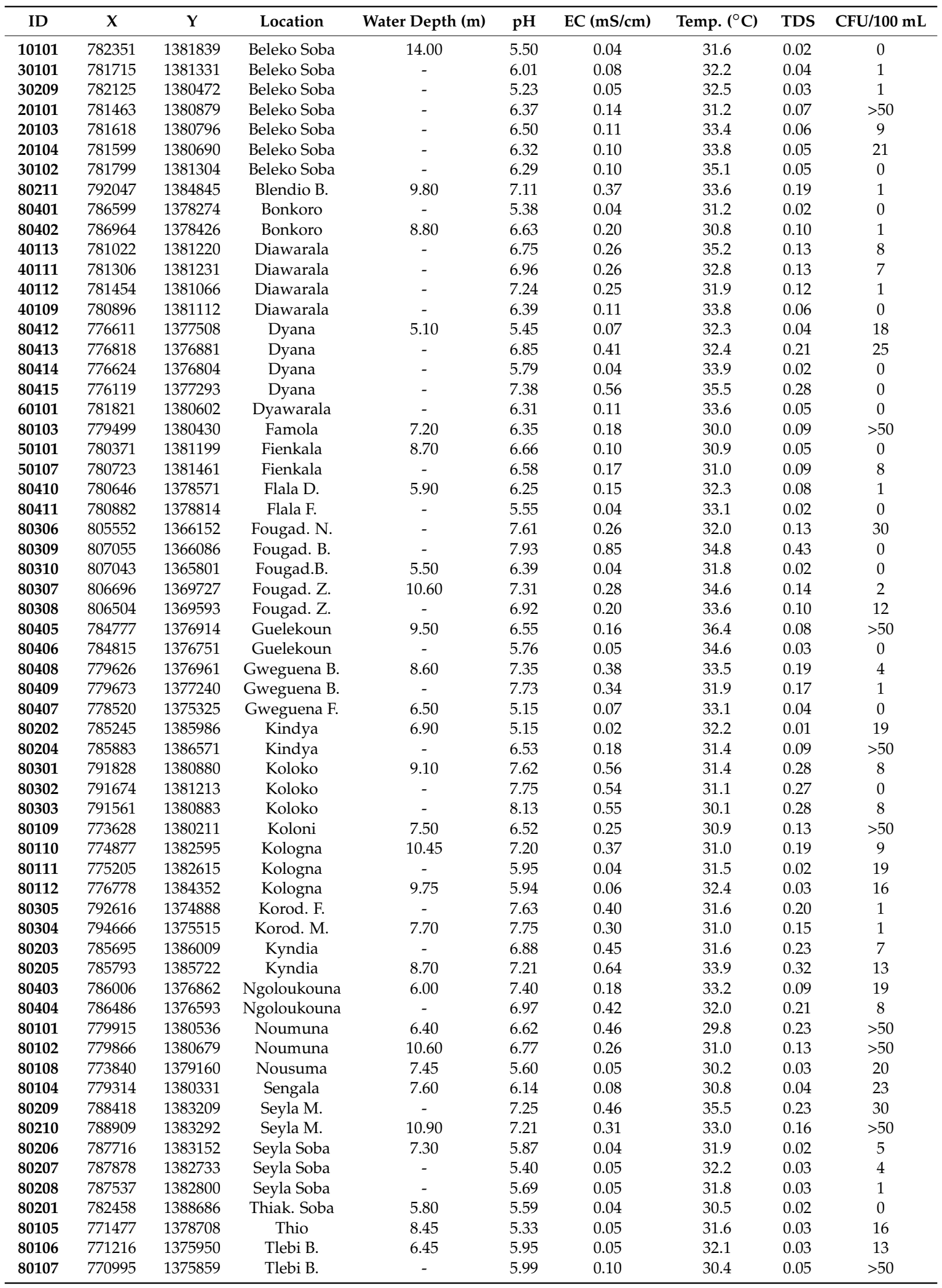


Figure 4 presents cumulative coliform-count curves for standpipes and hand pumps. The average cumulative curve falls closer to the hand pumps because these are significantly more numerous. Overall, hand pumps present a greater degree of contamination. Only $20 \%$ of the samples rendered a zero count, while about $40 \%$ resulted in a coliform content between 1 and $10 \mathrm{CFU}$. Instead, $57 \%$ of the standpipes present no contamination and $71 \%$ less than $10 \mathrm{CFU}$. This means that only $25 \%$ of the water sources are coliform-free, and that a further $37 \%$ are within possibly tolerable values (i.e., less than $10 \mathrm{CFU} / 100 \mathrm{~mL}$ ).
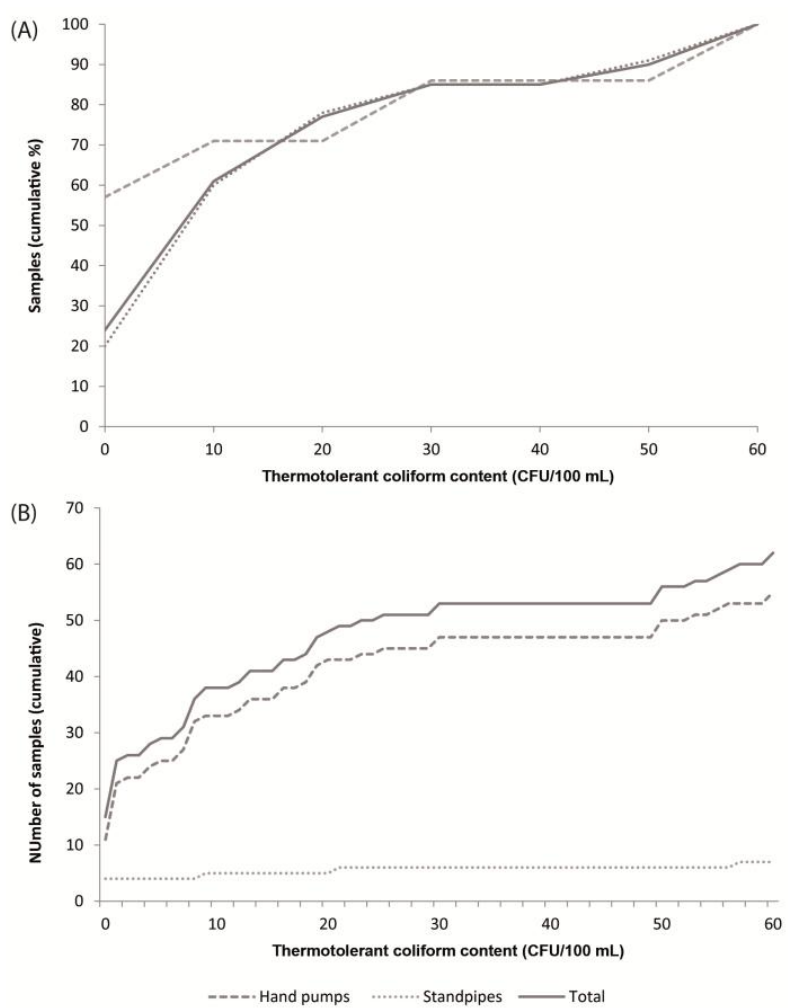

Figure 4. (A) Cumulative percentage of samples per thermotolerant coliform content and improved water source type $(n=62)$; (B) cumulative number of samples per thermotolerant coliform content and improved water source.

A variety of contamination sources were detected in close proximity to supply points. These include latrines, animal presence and excrement, or agricultural land. Visual inspection revealed uncontrolled waste disposal to be widespread, both above the ground and in shallow pits.

Hand pumps are located directly at a borehole and lift the water from within. Since boreholes are seldom chlorinated, the degree of protection depends on how well built the sanitary seal is and on whether the borehole is sufficiently far away from contamination sources. Standpipe contamination is more difficult to assess. In the case at hand, there are four villages with standpipes associated with water towers. The tanks located in two villages were damaged, meaning that all related standpipes were inactive, while the one in a third village, serving several standpipes, could not be sampled for logistic reasons. Hence, only one water tower could actually be analyzed. When asked, the guardian said that he treated the infrastructure with a roughly appropriate volume of bleach twice a year. The tank sample tested negative for chlorine residual, but it also rendered zero thermotolerant coliforms. Microbiological contamination was, however, found at some of the associated standpipes. This suggests that contamination takes place either along the pipes or at the faucet. Visual inspection revealed both alternatives to be plausible. For instance, a public latrine was identified right next to a standpipe that rendered a large number of coliforms ( $>50 \mathrm{CFU} / 100 \mathrm{~mL}$ ). Leaks from the septic pit could easily reach the shallow underground pipe, thus contaminating the distribution network. This is particularly likely 
because flow along the pipes is intermittent, which results in reversed hydraulic gradients during downtime [59].

Poor quality lowers the actual drinking water coverage per surface area dramatically (Figure 5). On average, coverage falls from $78 \%$ to just $39 \%$ across the commune. Small villages such as Sengala or Famola, which are served by a single hand pump each, automatically fall from $100 \%$ to $0 \%$ due to their boreholes being contaminated (Figure 6A). In other cases, small size is an advantage. Take, for instance, Flala Damene and Flala Fahiri, which are located right next to each other. The former owns one single hand pump, which is contaminated. However, its coverage remains close to $100 \%$ because the pump within the latter is safe and sufficiently close for its buffer area to span both villages.

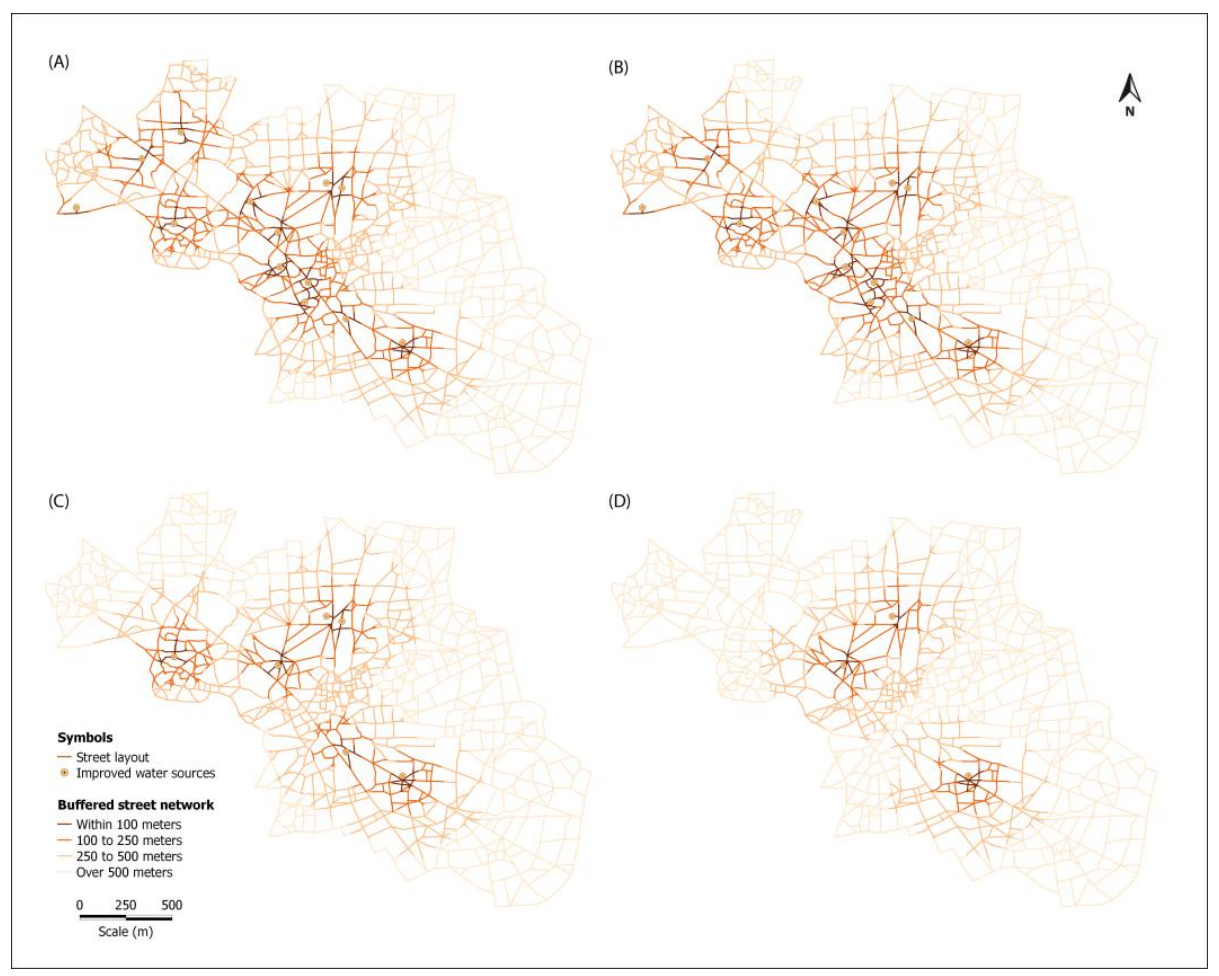

Figure 5. Distance to improved water sources in Beleko-Soba (one-way trip): (A) all improved water sources; (B) only serviceable sources; (C) good-quality improved water sources; and (D) cost-free, good-quality improved water sources.

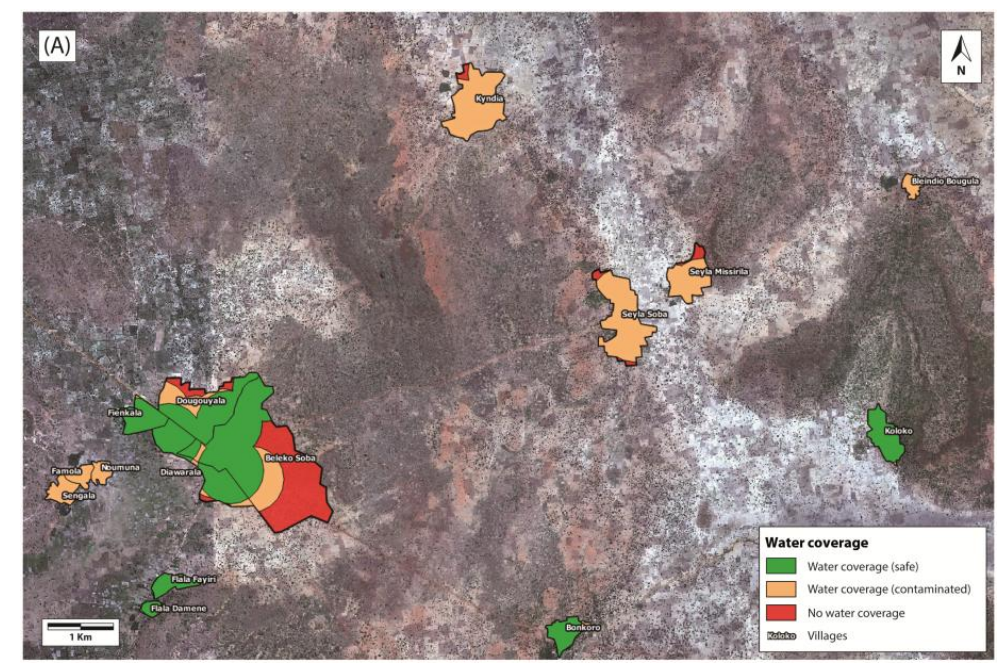

Figure 6. Cont. 

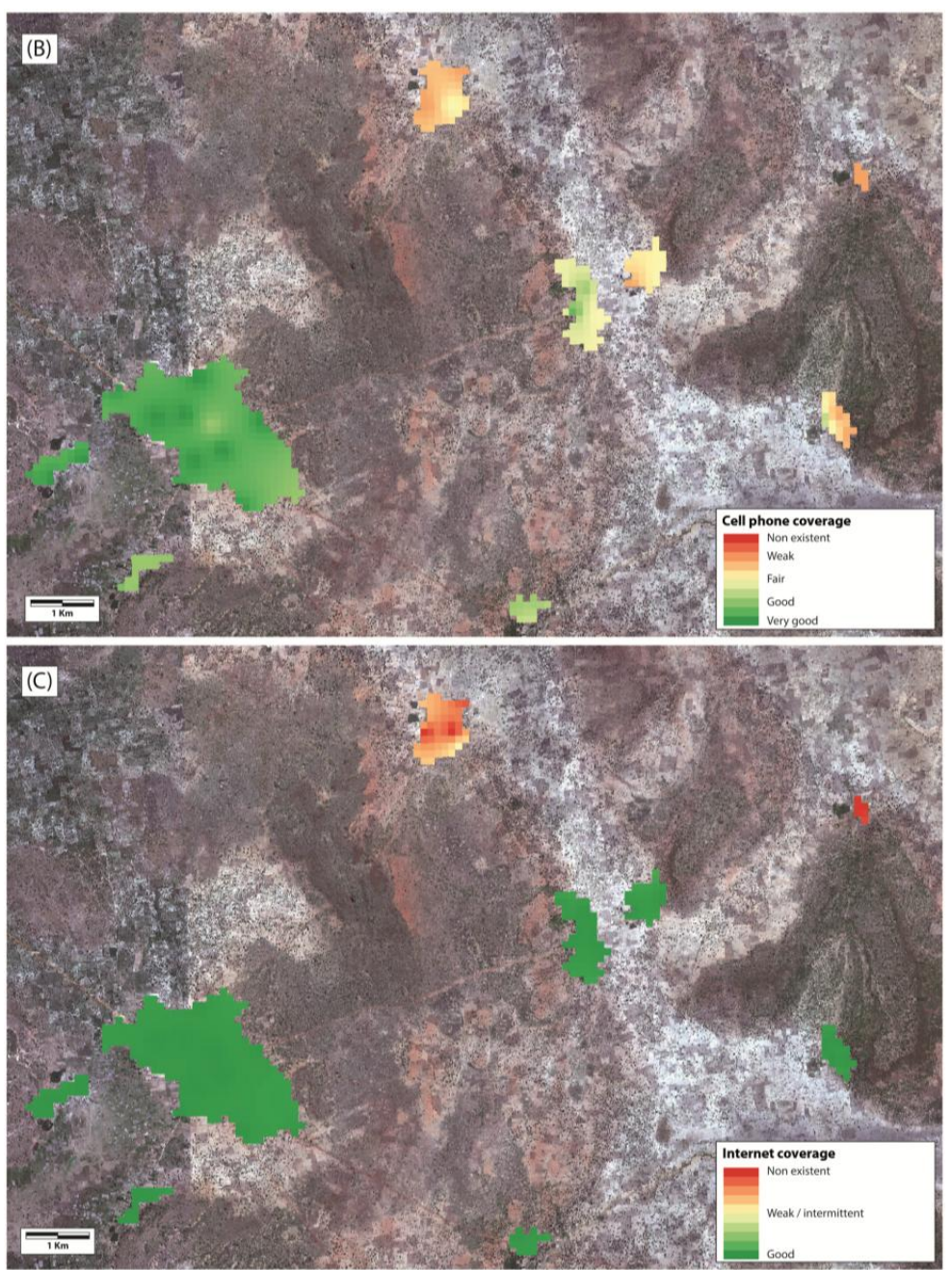

Figure 6. (A) Water coverage as per the quality of the source in selected villages; (B) cell phone connectivity; (C) Internet coverage. Note that the cell phone and Internet scales are not comparable.

On average, a hand pump or standpipe supplies enough water to meet the daily needs of 300 to 500 people. If all 86 water sources were operative, the average for the commune would be about one pump for every 407 people. This is roughly appropriate, although the average masks a wide range (from one pump per 106 inhabitants in Diawarala to one for 2470 in Korodougou Markala). Nevertheless, the truth is that only 11 villages out of 30 have some degree of access to safe water. Not taking into account the 500-m rule, this amounts to one adequate source for every 830 people in those villages, ranging from one in 309 in Flala Fahiri to one in 2344 in Beleko Soba.

\subsection{Wireless Coverage}

Figure 7 displays the area's telecommunication infrastructures. Several conclusions come to mind: (1) the distribution of telecommunication towers in the area is irregular; (2) towers are located mostly along the main roads; and (3) towers are considerably more abundant towards the west (i.e., towards the capital, Bamako) than towards the east (the border with Burkina Faso).

Three typologies of rural communes can be distinguished based on these observations. The first typology corresponds to peri-urban areas around major towns (i.e., Bamako and Koulikoro). These are considerably well endowed with telecommunications infrastructures, coverage being redundant in many cases. The second type includes communes traversed by an important road (or major unpaved track) and with at least one tower. Adjoining communities with no towers may be included in this 
category, provided the signal is strong enough. Finally, the third type includes communes with limited transport infrastructure. Towers are absent in most cases, meaning that most of these areas have little or no access to telecommunications. Djedougou is approximately halfway between Bamako and Burkina Faso, within the medium-density area. It is close to a major track and well-endowed with towers. Hence, it can be considered representative of the second typology.

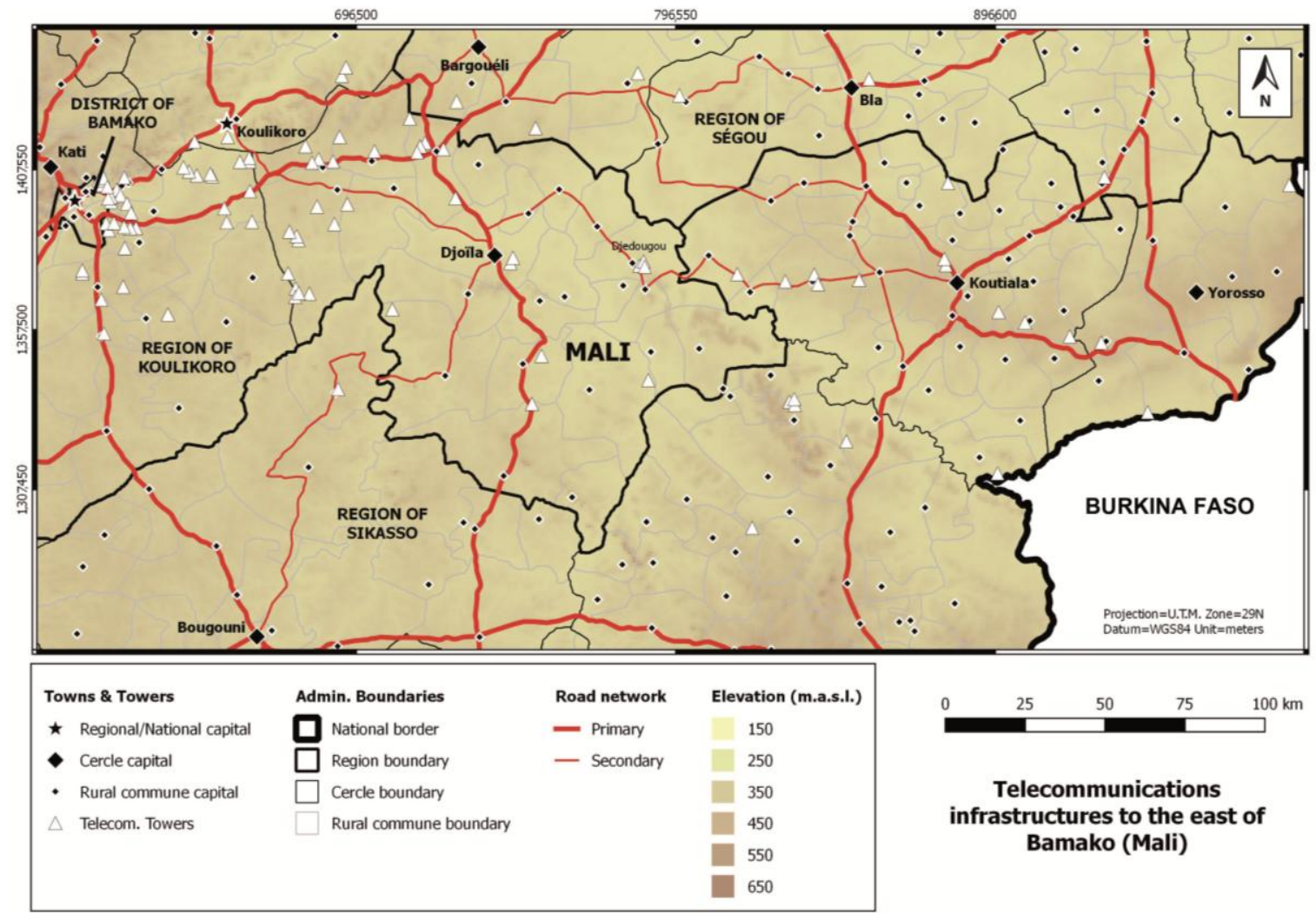

Figure 7. Telecommunications towers around the rural commune of Djedougou. Data from opensignal.com. Towers within the Bamako District are not displayed.

Figure 8 showcases the results of the telecommunications survey. Some care should be taken when interpreting the outcomes. In the first place, it should be noted that these provide a snapshot of wireless coverage at a given moment, which corresponds to the time of the field survey. A longer investigation would be required to establish whether this changes significantly over time, but first-hand experience suggests that the results are representative: over the last two years the authors have spent several months working in and around Beleko-Soba. Internet and cell phone coverage have been reliable most of the time, allowing for daily telephone calls, texting and e-mail connections. Coverage gaps were largely sporadic. The only real exception to this rule was a one-week break associated with the implementation of the 3G service in spring 2015.

In any case, coverage standards are lower than one would expect in industrial countries. Lightweight messaging applications such as the ones we used require little bandwidth. As a result, these tend to overstate the quality of connections. Outcomes should thus be interpreted with some flexibility: a "good" qualification for Internet coverage means a "stable" or "reliable" connection, but does not imply that it is fast or good enough to download large files.

Overall, cell phone and Internet connectivity are widespread in the commune, except for the northeast and southeast sectors. Factors constraining coverage usually include land features, infrastructures, proximity to major roads, network capacity, and antennae locations. In this case, the latter two are the most likely candidates to explain the presence of dead spots, as there are no major 
mountains or obstructing elements such as underpasses or tunnels. Weak coverage is mostly found in sparsely populated areas, but most villages are reasonably well supplied. In fact, approximately $95 \%$ of the village surface area has at least intermittent cell phone connectivity, while $91 \%$ has at least intermittent Internet connectivity (Figure 9). This provides a stark contrast with the drinking water coverage, which is below $40 \%$. Both values also exceed the maximum water coverage, i.e., the coverage there would be if all improved sources were operational and contamination-free $(82 \%)$.

(A)
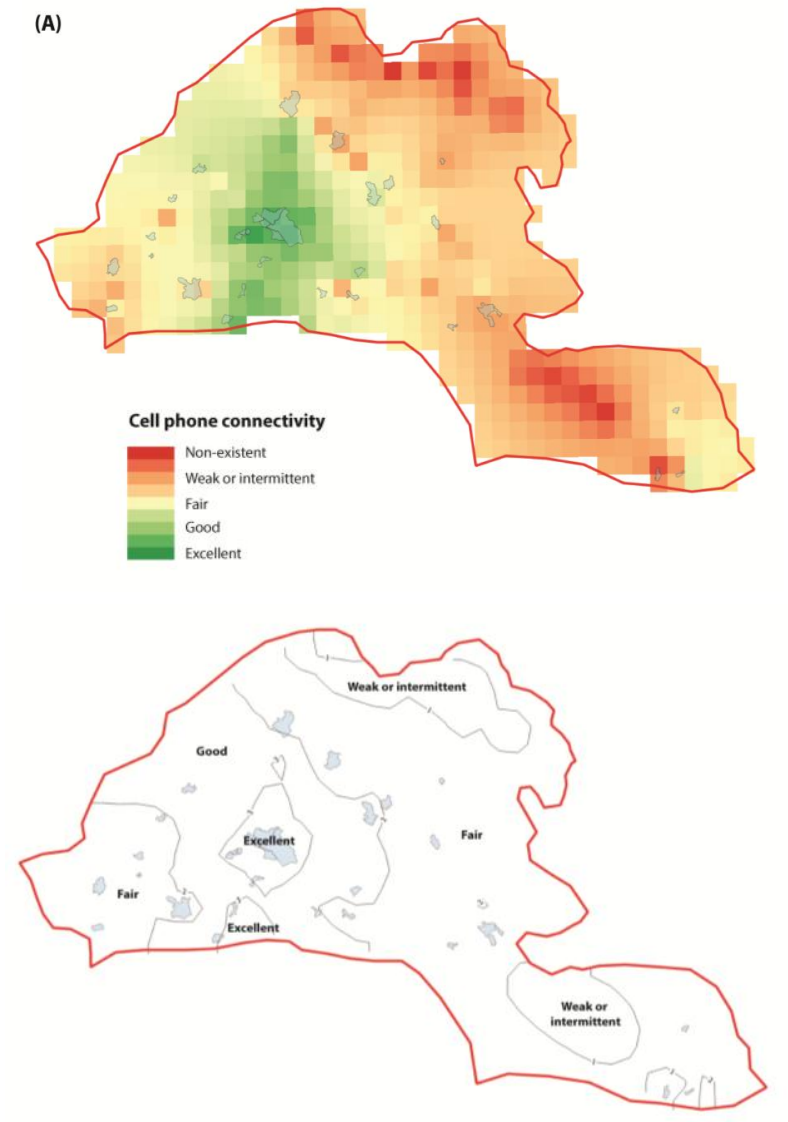

(B)
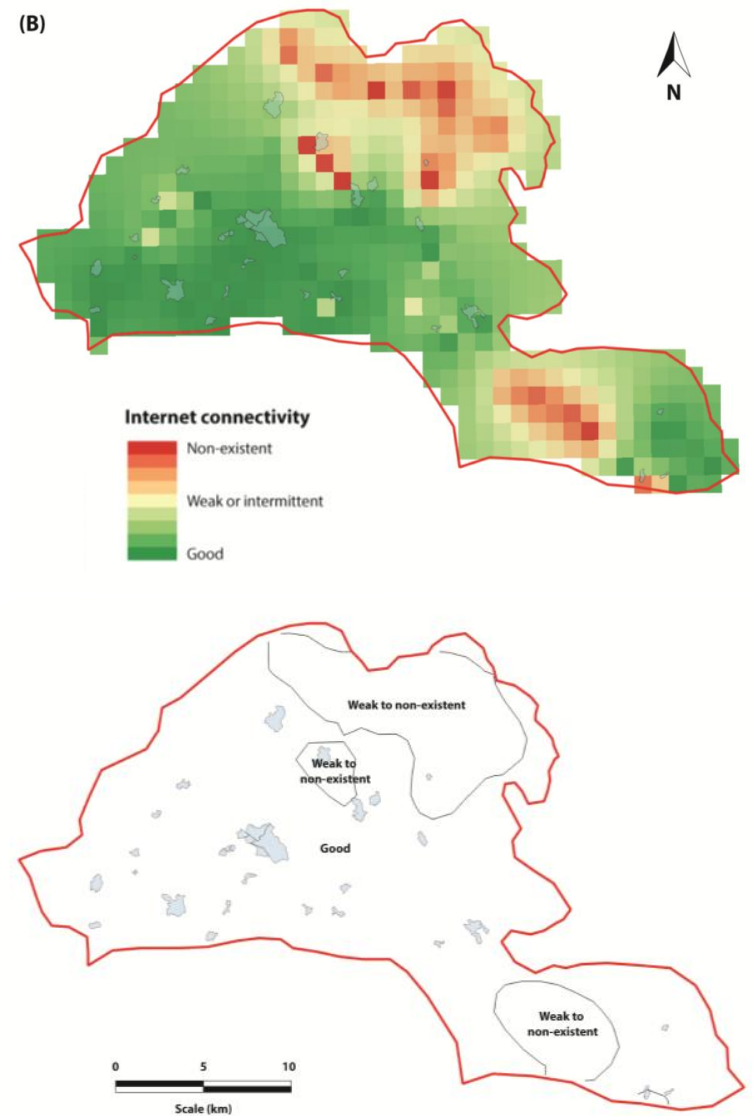

Figure 8. Telecommunications coverage across the rural commune of Djedougou. (A) Cell phone connectivity; (B) Internet coverage. Note that the maps are not comparable on the basis of colors, as the scales are different.

Apparent discrepancies were found in wireless coverage (Table 3). For instance, there are several villages where the Internet connection is "good" throughout and simultaneously "fair" or "weak or intermittent" cell phone coverage (Figure 10). This can be attributed to three different factors. The first is linked to geostatistical dispersion. Since raster maps are obtained by interpolating point-source information, some uncertainty can be expected for those areas where no field readings were collected directly. The second aspect has to do with instantaneous fluctuations in coverage (coverage can vary slightly over time while staying in the same spot). This is due to a variety of causes, including terminal performance, environmental conditions, and fluctuations in the network. Finally, there is the issue of scale. Internet and cell phone coverage scales are analogous to an extent, but not strictly comparable. All this means that the methodology can do with some refinement if more accurate results are to be obtained. However, the available outcomes are considered sufficiently precise for the purpose of this work. 

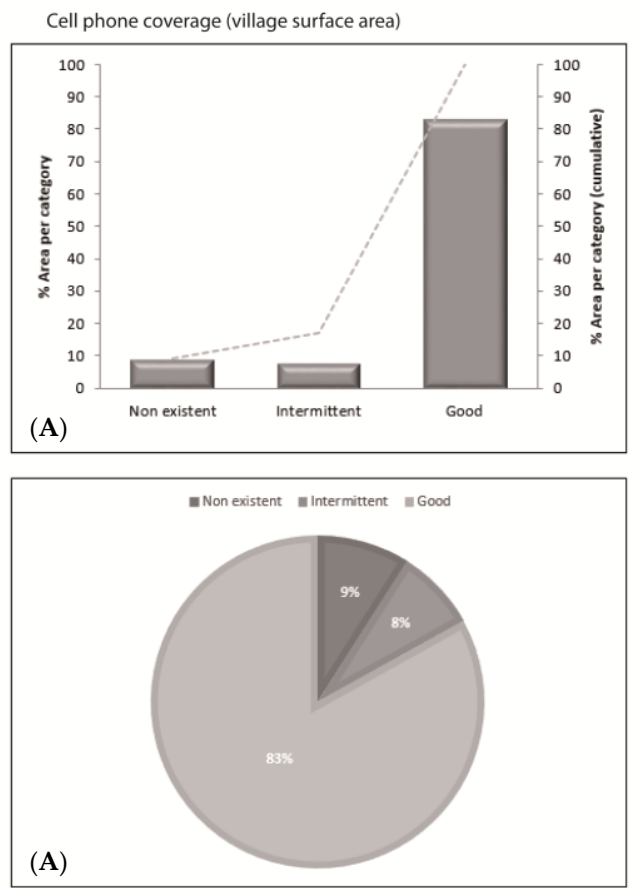
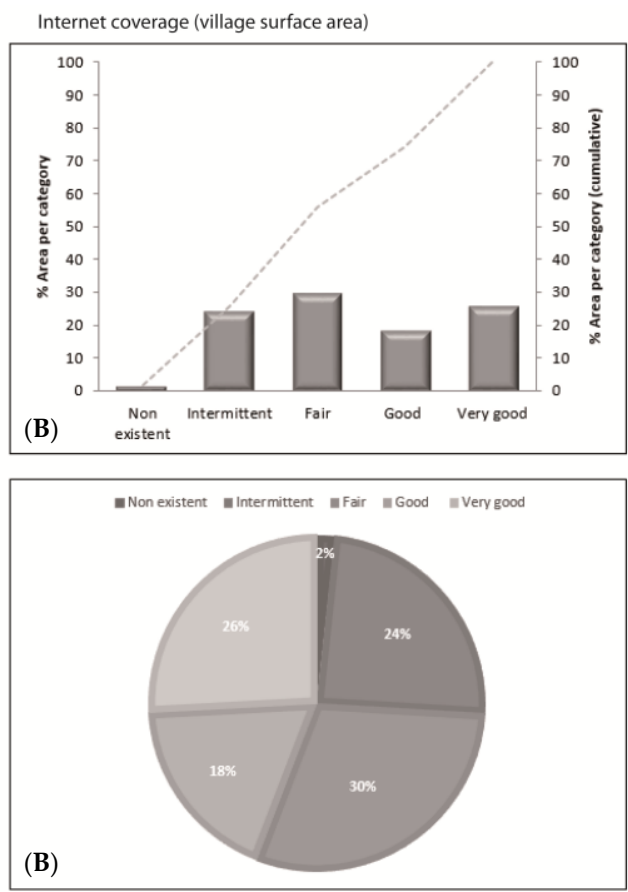

Figure 9. Coverage level expressed in terms of village surface area for (A) cell phone coverage and (B) Internet coverage.

Table 3. Internet and cell phone coverage in Djedougou villages, expressed as percentage surface area. Results stem from geospatial interpolation of over 300 coverage readings gathered across the rural commune.

\begin{tabular}{|c|c|c|c|c|c|c|c|c|}
\hline \multirow{2}{*}{ Village } & \multicolumn{5}{|c|}{ Cell Phone Coverage (\% Surface Area) } & \multicolumn{3}{|c|}{ Internet Coverage (\% Surface Area) } \\
\hline & Non-Existent & $\begin{array}{c}\text { Weak or } \\
\text { Intermittent }\end{array}$ & Fair & Good & Excellent & Non-Existent & $\begin{array}{c}\text { Weak or } \\
\text { Intermittent }\end{array}$ & Good \\
\hline Beleko Soba & 0 & 0 & 15 & 72 & 13 & 0 & 0 & 100 \\
\hline Bleindio B. & 14 & 86 & 0 & 0 & 0 & 100 & 0 & 0 \\
\hline Bonkoro & 0 & 0 & 40 & 60 & 0 & 0 & 0 & 100 \\
\hline Sengala & 0 & 0 & 0 & 27 & 63 & 0 & 0 & 100 \\
\hline Dyana M. & 0 & 21 & 79 & 0 & 0 & 0 & 0 & 100 \\
\hline Diawarala & 0 & 0 & 0 & 26 & 74 & 0 & 0 & 100 \\
\hline Dougouyala & 0 & 0 & 1 & 74 & 25 & 0 & 0 & 100 \\
\hline Famola & 0 & 0 & 0 & 44 & 56 & 0 & 0 & 100 \\
\hline Fienkala & 0 & 0 & 0 & 42 & 58 & 0 & 0 & 100 \\
\hline Flala D. & 0 & 0 & 83 & 16 & 0 & 0 & 0 & 100 \\
\hline Flala F. & 0 & 8 & 85 & 8 & 0 & 0 & 0 & 100 \\
\hline Fougad. B. & 0 & 0 & 83 & 17 & 0 & 0 & 0 & 100 \\
\hline Fougad. N. & 86 & 14 & 0 & 0 & 0 & 47 & 53 & 0 \\
\hline Fougad. Z. & 0 & 71 & 29 & 0 & 0 & 0 & 0 & 100 \\
\hline Gueguena B. & 0 & 0 & 21 & 36 & 43 & 0 & 0 & 100 \\
\hline Gueguena F. & 0 & 0 & 70 & 25 & 5 & 0 & 0 & 100 \\
\hline Guelekoun & 0 & 33 & 67 & 0 & 0 & 0 & 0 & 100 \\
\hline Kyndia & 0 & 68 & 32 & 0 & 0 & 0 & 0 & 100 \\
\hline Kologna & 0 & 0 & 71 & 29 & 0 & 0 & 0 & 100 \\
\hline Koloko & 0 & 62 & 29 & 9 & 0 & 0 & 0 & 100 \\
\hline Koloni N. & 0 & 0 & 100 & 0 & 0 & 0 & 0 & 100 \\
\hline Korod. F. & 0 & 37 & 63 & 0 & 0 & 0 & 0 & 100 \\
\hline Korod. M. & 10 & 83 & 7 & 0 & 0 & 15 & 11 & 74 \\
\hline Ngolokouna & 0 & 85 & 15 & 0 & 0 & 0 & 0 & 100 \\
\hline Noumouna & 0 & 0 & 0 & 14 & 86 & 0 & 0 & 100 \\
\hline Seyla M. & 0 & 24 & 76 & 0 & 0 & 0 & 0 & 100 \\
\hline Seyla Soba & 0 & 0 & 70 & 28 & 2 & 0 & 0 & 100 \\
\hline Thio & 5 & 74 & 21 & 0 & 0 & 0 & 0 & 100 \\
\hline Thiak. Soba & 0 & 69 & 27 & 4 & 0 & 2 & 83 & 15 \\
\hline Tlebi B. & 0 & 12 & 88 & 0 & 0 & 0 & 0 & 100 \\
\hline
\end{tabular}



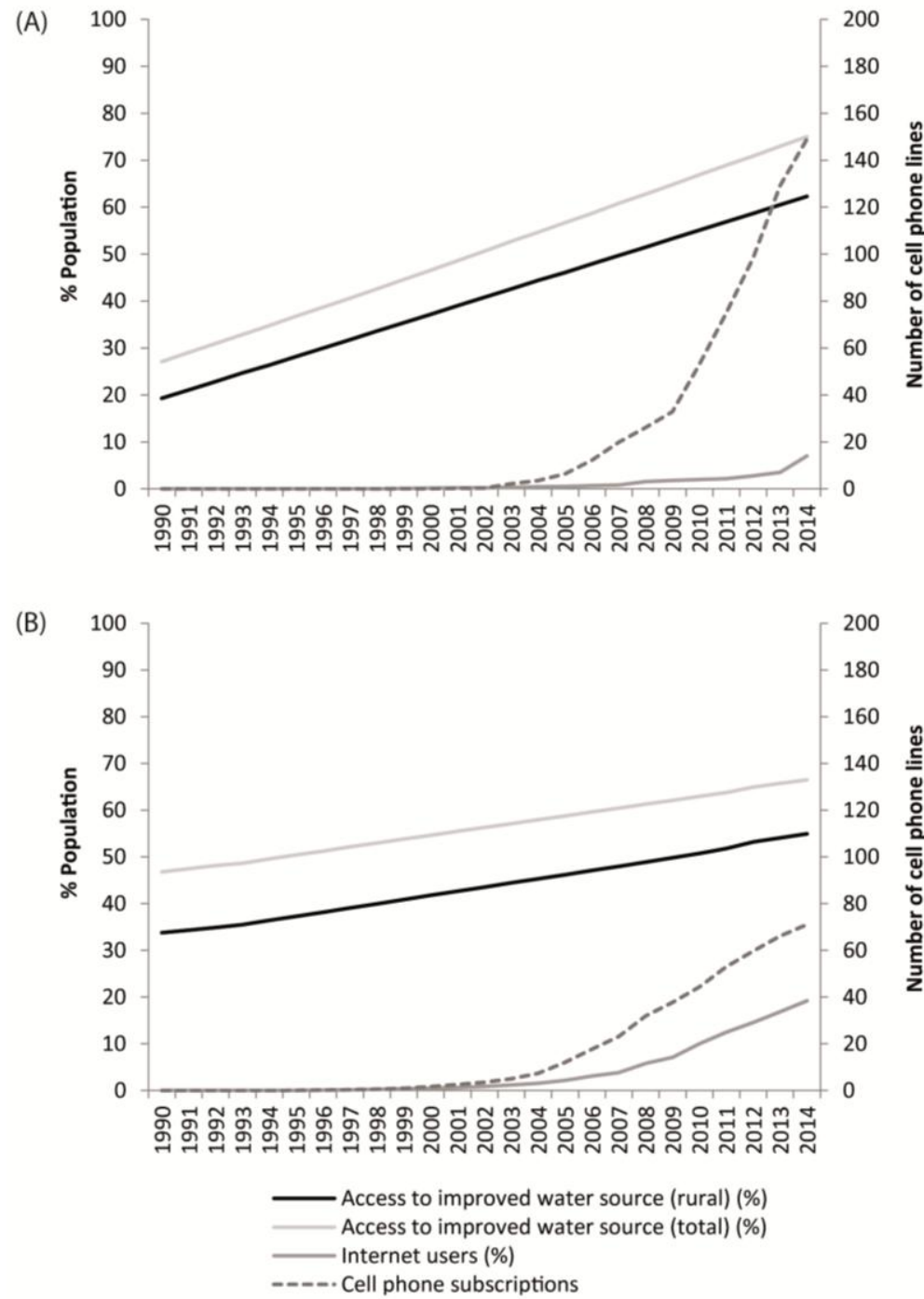

Figure 10. Access to improved water sources vs access to telecommunications in (A) Mali and (B) Sub-Saharan Africa [10].

\subsection{Outcomes of the Survey of Water Committees}

For items (a) and (b) of the survey, water committee members were asked to provide a rating ("good," "fair," or "poor") and then to further qualify it in their own words. The majority of them answered "good" for the state of the infrastructure (73\%) and the level of service $(67 \%)$. This is roughly coherent with our direct observations, in view of the fact that approximately $78 \%$ of the improved water sources remain serviceable on a permanent basis. Those ratings "fair" or "poor" referred to village-specific issues. These mostly include the representatives from the three villages served by broken water towers, who explained that they were experiencing different difficulties in repairing the networks. Only one of the interviewees referred to water quality, explaining that some of the hand pumps yielded turbid water.

The interpretation of open-ended items (c) and (d) requires some historical background. The first improved sources of Djedougou were installed in the 1980s by the joint initiative of the government and international agencies. The number of improved water sources grew progressively between 1980 and 2010, mostly owing to population increase. Unfortunately, the absence of effective operation and maintenance strategies gradually caused most of the infrastructure to fall into disrepair. By 2010 only $20 \%$ of the improved water sources were serviceable. The work of non-profit organizations 
contributed to a reversal of the trend in recent years, raising the share of operational sources to about 80\% by late 2013 (78\% as of June 2016). Efforts to improve water coverage led to the development of basic maintenance schemes, including the installation of water committees. Payment mechanisms were developed for public water sources so that there would be funds to fix broken infrastructure. In addition, two repair kits were purchased and many local technicians were trained to fix common hand pump malfunctions in exchange for a small remuneration. The repair kits are kept in Beleko-Soba, where the technicians may collect them every time there is a need.

Within this context, all interviewees cited water committees as one of the three main reasons why the infrastructure has been regularly serviceable in the last five years. Direct observation suggests that this is true. However, there is some potential bias in this question, as all interviewees were members of local water boards. Most (87\%) also mentioned the importance of having repair kits and trained technicians. The presence of non-profit organizations (53\%) was identified as the next most important factor. The main aspects to be improved include funding ( $93 \%)$, the need to develop additional water sources $(67 \%)$, and queues ( $33 \%)$.

The need to train technicians beyond fixing hand pumps provides an interesting case. This was identified as the single most important need by four representatives (27\%), but it was not mentioned at all by the others. A likely reason is that water towers and standpipes are only present in four villages, and three of them are currently experiencing major maintenance problems: at the time of the survey, $64 \%$ of the tower-dependent standpipes in the commune were out of service, in contrast with just $8 \%$ of hand pumps.

Items (e) through (h) were open-ended and referred to the role of telecommunications in local water management. In relation to items (e) and (f), all committee members declared that they own cell phones, while most (80\%) acquired their first cell phone after 2010 . In contrast, only $7 \%$ use an Internet connection. When asked whether they ever used cell phones for committee-related tasks (g), all of them answered in the affirmative. Item (h) aimed at establishing how they perceive that access to telecommunications helps them fulfill their roles as committee members. All agreed that communicating via cell phones made their work more efficient. Some of the common tasks include calling meetings, contacting technicians, coordinating actions, or getting spare parts delivered. The practical implications of these answers are discussed later on.

\section{Discussion}

\subsection{Coverage versus Access}

A clear distinction needs to be made between coverage and access. This dichotomy has been the object of different discussions in the literature [60-62]. For the purposes of this research, the coverage notion is simple enough, as it represents the presence of the resource. On the other hand, access is a rather complex concept that not only depends on availability, but also on additional action, purpose, and means on the part of a prospective user. This means that coverage is a prerequisite for access, but that the opposite is not true. In other words, the fact that a resource is physically available does not mean that people will access it: many villagers will not use the existing improved water sources if they perceive them to be too expensive or if these are located too far away from their homes; similarly, they will not make use of the wireless network if they do not own a cell phone. Therefore, coverage figures represent theoretical maxima, rather than an accurate depiction of daily habits.

The complexity of the access concept often leads to expressing the results of spatial surveys in terms of coverage [63]. This is the method of choice in geographical settings such as the one at hand, where obtaining reliable data is logistically complicated. Thus, results in this case have been presented in terms of coverage per surface area. Translating coverage area into population figures can only be done under the assumption of uniform population density. This means that coverage could have been underestimated in those cases where population is denser in the immediate vicinity of water points 
(and vice versa). Similar precautions apply to wireless communications. This is a limitation that cannot be overcome without extremely detailed household information.

On paper, access to water in Mali has been growing steadily over the last three decades. About two-thirds of the population have access to improved water sources, up from just one-third in the early 1990s. This is no doubt a consequence of national and international investments carried out in the context of the Millennium Development Goals. However, indicators can be misleading [64]. Water access is almost invariably measured as "the proportion of the population with access to an improved water source". Yet, as shown by this survey, the fact that the drinking water is taken directly from an improved source does not necessarily ensure that the water is safe. This finding is consistent with many examples in the literature [65-67].

The absence of trained technicians and testing equipment means that improved water sources in the area (and in rural Mali in general) are unmonitored. The closest water laboratory is located in the capital, Bamako, four hours away by car. Road communications include a long stretch of unpaved track that can be left in very poor condition during the wet season. There is also a marked absence of protection mechanisms around improved water sources. Latrines are routinely built in close proximity to water supply boreholes and standpipes. Further water points are developed as the population grows, but there is no coordinated strategy to address the quality problem. Hence, it is unlikely that this situation will change in the near future.

Even when drinking sources are improved and treated, there are a variety of ways in which water can get contaminated, both at the source and along the way to the faucet, thus making it inappropriate for human consumption [68,69]. Widespread habits such as collecting and carrying water in dirty buckets are also likely to introduce contaminants in drinking water before it is consumed. Thus, although most people in the study area can get water from improved sources, water quality remains an important problem. Largely as a result, waterborne disease is common, particularly among children. All this means that it is pertinent to re-assess the alleged success that many countries have enjoyed in meeting the Millennium Development Goals [4]. Moreover, international organizations should further refine global indicators so as to gain a more accurate perspective on the current state of affairs around the world. This is particularly important to prevent investments from being reallocated away from a sector that remains in need [70].

Furthermore, measuring access in terms of the presence of improved water sources overlooks important aspects such as reliability, quality, quantity, collection time, or cost $[57,62,71]$. As explained, cost and quantity appear to be relatively unimportant in the case at hand, but the existence of inactive and contaminated water sources suggests that national figures are also likely to overestimate the share of the population with actual access to safe drinking water. In this sense, Mali appears to be similar to other low-income countries [72-75].

Telecommunications are different. Mali is one of the world's greatest achievers in terms of closing the digital divide in cell phone usage $[17,76]$. Figure 9 shows telecommunications versus water coverage in Mali and sub-Saharan Africa. Trend-wise both geographical contexts are similar, suggesting that Mali provides an appropriate benchmark for the region. Cell phone usage was practically non-existent across the continent until about 2005, but has rocketed since. The country currently boasts 150 cell phone subscriptions per 100 inhabitants (that is, one and one-half subscription per person), a figure that continues to grow and shows no sign of slowing down [16]. This is readily observed in the streets, even at the village level, where many people own one cell phone for each of the two mainstream network providers. This is mostly due to pricing policies, which make phone calls from one company to another extremely expensive.

While traditional telephone lines are inexistent, many people in the study area own at least one cell phone and use it regularly. For those who do not, the potential of sharing should not be overlooked [77]. In contrast, the Internet shows a much more modest penetration rate. Only $7 \%$ of people in Mali are Internet users. Thus, the country trails behind West African neighbors Nigeria $(43 \%)$, Ghana (19\%), Senegal (18\%), or Cote D'Ivoire (15\%). Statistics show that Internet usage has 
nearly quadrupled in Mali over the last five years (from 2\% to 7\%), a growth rate that doubles that of sub-Saharan Africa (19.2\% to 10\%) [16]. This rapid expansion possibly reflects the sheer amount of people who are yet to adopt new technologies.

In the case at hand, widespread Internet coverage does not mean that people have access to the network. In fact, very few people do. Van Dijk and Hacker [78] point out that the inability of people to bridge the digital divide is often driven by several factors, including the lack of elementary digital experience, as well as the absence of computers and network connections, digital skills, or meaningful usage opportunities. In terms of Internet use, these are all relevant in an area in which the adult literacy rate is as low as $33 \%$.

There is, of course, some asymmetry in comparing water and wireless coverage. Everyone in the study region has the possibility of using some form of water source because water is essential for life. People lacking an improved water source will use unimproved sources (i.e., shallow unprotected wells), whereas if people lack telecommunications coverage they will simply be unable to use their cell phone or the Internet. This highlights how villagers have more agency over their water supply, as they can develop their own source at the local level and are therefore less dependent on formal services. In contrast, access to telecommunications is entirely reliant on the infrastructure network and formal services. Moreover, there is an issue of physical materiality. Water services can only be provided where the infrastructure is, whereas one single telecommunications tower can serve a large expanse of land with no direct physical presence in the area. This explains why telecommunications may cover very large surfaces with relative ease, while the water sector continues to struggle to reach a basic coverage level in many regions.

\subsection{Exploring the Connections}

At first sight, water and telecommunications may look like completely unrelated resources. In practice, however, the nexus is becoming increasingly important. In the case at hand, the answers provided by water committee members to items (g) and (h) of the survey constitute evidence that widespread cell phone access is helping water committees to act more efficiently, thus maintaining water sources in good working condition. Here are some examples:

"All the pumps in the village work. The technician is quick to come when we call him even though he lives far away." [Interviewee \#1].

"Three or four years ago we [the water committee] did not meet very often. One person would have to travel around trying to come up with a moment that suited us all. Some of the committee members live in other villages, so getting everyone to come was difficult. Since we all bought cell phones meetings have become more frequent." [Interviewee \#4].

"In the past there were times when water committees took a long time to find out about broken pumps. Pumps could take months to fix. This no longer happens. Even if a village has no member in the committee or if the member is away, anyone there can make the call and let us know that there is a problem." [Interviewee \#11].

These all highlight how wireless telecommunications are gradually managing to overcome the issue of transport. Many African villages are still linked by unmaintained tracks, which implies that short distances take a long time to travel. In fact, living far from a major road has long since been identified as a basic impediment to rural development [79]. In this context, wireless telecommunications have proven extremely valuable in enhancing everyday transactions. This is particularly important in markets where a large share of the business operations are carried out among individuals or small firms and where extensive travel was previously required for sellers to meet buyers $[26,27]$. The same applies to management tasks such as those carried out by water committees. The widespread availability of cell phones means that problems can be identified quickly, that technicians can be contacted, and that they can coordinate their activity in order to be as efficient 
as possible. Phone calls also allow users to have an estimate as to how long the downtime is likely to last.

A second important aspect is related to the fact that spare parts can only be bought in major urban centers. By using their telephones, technicians can order them in advance, and, if needed, only make the trip once they know that the pieces are in stock. Alternatively, they may have them delivered by truck. This reduces maintenance costs and contributes to a more efficient use of human and material resources:

"Before, when the pump broke, we had to raise funds to fix it. Some people would not want to pay and that created conflicts. Then we had to travel to Fana or to Djoila to find a technician and hope for him to come quickly. He would usually take a long time because we could not stay there to press him and because he sometimes had to travel to Bamako to buy spare pieces. Now we have local technicians and repair kits. We call them whenever there is a problem and they come quickly. If we need spare parts, we can call and have them delivered from Bamako in a day or two. This saves us a lot of time and money". [Interviewee \#9].

These aspects may appear to be of elementary relevance when viewed through the lens of industrial societies. However, their practical relevance in rural developing contexts cannot be overstated. Adequately maintained hand pumps reduce fetching times and distances, facilitate personal hygiene, and minimize the risk of illness and physical injury. They also free up time for education and leisure among children and, overall, improve the living conditions of the people. Hence, the use of wireless communications provides a welcome addition to community-based water management in the region.

Pritchett and Woolcock [80] provide an interesting framework for comparison by highlighting the differences between transactional and discretional tasks. Public services such as water supply are discretionary to the extent that their delivery requires decisions by providers to be made on the basis of information that is important but inherently imperfectly specified and incomplete. In practice, this means that these cannot be mechanized. These decisions usually entail extensive professional or informal context-specific knowledge. On the other hand, transaction intensiveness refers to the extent to which the delivery of a service requires a large number of transactions, nearly always involving some face-to-face contact. In this context, it could be argued that communication is a purely transactional task, as opposed to water services, which are a mixture of tasks with high transaction intensiveness and high discretion. Indeed, tasks within rural water services that are purely transaction-intensive (e.g., contacting the technician, contacting committee members), could be tackled successfully as coverage improves and as cell phones become available to as many people as possible. However, discretionary tasks within water services require improvements in institutional capacity within the rural water sector in order to be effectively tackled.

\section{Conclusions}

Access to safe water has improved over the last few decades in sub-Saharan Africa. This is largely a consequence of commendable efforts on the part of governments, international organizations, and other relevant actors. However, there is still plenty of room for improvement. This research highlights several important paradoxes. The first has to do with the fact that theoretically safe water supplies (i.e., improved water sources) do not necessarily provide clean water. This is a relevant finding because global statistics are concerned with relatively shallow indicators that ignore the quality or level of service. In rural environments, inadequate operation and maintenance strategies have resulted in overestimating the number of people who actually have reliable access to safe water. Official figures need to be reassessed in order to devise a more accurate picture of the current situation, as well as to prevent the focus from switching to other problems before this one is solved.

The second paradox has to do with the relevance of water and telecommunications for human existence. Safe water is needed for many daily tasks and is essential to survival. However, accessibility 
is poor when measured beyond headline indicators. On the other hand, wireless coverage is already better than water coverage in many developing regions despite the fact that telecommunications is a relatively new development and not indispensable for human life. Further research is needed to evaluate which aspects of the telecommunications industry can be translated into the water sector, so as to enhance the results of those initiatives and investments that seek to improve water access across the world. For the time being, the Djedougou experience shows that improving wireless telecommunications can make a welcome difference to the operation and maintenance of water supplies.

Will Internet access become universal before water access? While this is hard to predict, an affirmative answer is not out of the question. The authors recently experienced what a situation like that would look like: during a three-month stay in a remote village of Mali, we found our e-mail connection to be consistently more reliable than our water.

Acknowledgments: This research has been funded by the Agencia Española de Cooperación al Desarrollo (AECID), under grants 2014/ACDE/005226 and 2016/ACDE/001953. For their time and support, the authors would like to thank Geólogos Sin Fronteras (Geologists without Borders), the journal editorial staff, and three anonymous reviewers. The authors provided the funds for publishing in open access.

Author Contributions: All authors contributed extensively to the results of this work. Pedro Martínez-Santos led the research and joined Beatriz Cano and José Antonio Cerván in carrying out the fieldwork. Silvia Díaz-Alcaide contributed to developing the GIS database and figures. All authors contributed to the manuscript preparation, analysis, and discussion.

Conflicts of Interest: The authors declare no conflict of interest. The funding sponsors had no role in the design of the study; in the collection, analyses, or interpretation of data; in the writing of the manuscript, or in the decision to publish the results.

\section{References}

1. United Nations. General Comment No. 15: The Right to Water. UN Committee on Economic, Social and Cultural Rights. Available online: http://www.refworld.org/docid/4538838d11.html (accessed on 25 May 2017).

2. United Nations. Resolution A/RES/64/292. United Nations General Assembly. Available online: http: / /www.un.org/en/ga/search/view_doc.asp?symbol=A/RES/64/292 (accessed on 25 May 2017).

3. World Health Organization-UNICEF. Progress on Sanitation and Drinking Water-2015 Update and MDG Assessment; UNICEF and World Health Organization: Geneva, Switzerland, 2015; p. 90. ISBN 9-789241-509145.

4. Martínez-Santos, P. Does $91 \%$ of the world population really have "sustainable access to safe drinking water"? Int. J. Water Resour. Dev. 2017. [CrossRef]

5. United Nations. Statement by Secretary General Koffi Annan. Available online: http://www.un.org/News/ Press/docs/2003/sgsm8707.doc.htm (accessed on 25 May 2017).

6. United Nations Children's Fund. UNICEF Water, Sanitation and Hygiene Strategies for 2006-2015. Available online: https://www.unicef.org/about/execboard/files/06-6_WASH_final_ODS.pdf (accessed on 25 May 2017).

7. Jewitt, S.; Ryley, H. It's a girl thing: Menstruation, school attendance, spatial mobility and wider gender inequalities in Kenya. Geoforum 2014, 56, 137-147. [CrossRef]

8. Shahidul, S.M.; Zehadul-Karim, A.H.M. Factors contributing to school dropout among the girls: A review of literature. Eur. J. Res. Reflect. Edu. Sci. 2015, 3, 2015.

9. United Nations. The Millennium Development Goals Report. Available online: http://www.un.org/ millenniumgoals/2015_MDG_Report/pdf/MDG\%202015\%20rev\%20\%28July\%201\%29.pdf (accessed on 25 May 2017).

10. World Bank. World Bank Data (2016). Available online: http://data.worldbank.org/ (accessed on 25 May 2017).

11. Auriol, E.; Blanc, A. Capture and corruption in public utilities: The cases of water and electricity in Sub-Saharan Africa. Util. Policy 2009, 17, 203-216. [CrossRef] 
12. Harvey, P.; Reed, B. Rural water supply in Africa: Building blocks for handpump sustainability. In Water, Engineering and Development Centre; Loughborough University: Leicestershire, UK, 2004; p. 281.

13. Foster, T. Predictors of sustainability for community-managed handpumps in Sub-Saharan Africa: Evidence from Liberia, Sierra Leone, and Uganda. Environ. Sci. Technol. 2013, 47, 12037-12046. [CrossRef] [PubMed]

14. Koehler, J.; Thomson, P.; Hope, R. Pump-priming payments for sustainable water services in rural Africa. World Dev. 2015, 74, 397-411. [CrossRef]

15. United Nations. Report of the special rapporteur on the promotion and protection of the right to freedom of opinion and expression, Frank La Rue. In United Nations General Assembly; Report A/HRC/17/27. Available online: http://www2.ohchr.org/english/bodies/hrcouncil/docs/17session/A.HRC.17.27_en.pdf (accessed on 25 May 2017).

16. International Telecommunication Union. ICT facts and figures. In ICT Data and Statistics Division; Telecommunication Development Bureau. International Telecommunication Union: Geneva, Switzerland, $2015 ;$ p. 6.

17. Groupe Speciale Mobile Association (GSMA). The Mobile Economy. In Sub-Saharan Africa; Technical Report; GSMA Intelligence: London, UK, 2015; p. 59.

18. Aker, J.C.; Mbiti, I.M. Mobile phones and economic development in Africa. J. Econ. Perspect. 2010, 24, 207-232. [CrossRef]

19. Fosu, I. Exploring the potential of wireless technologies to accelerate universal Internet access in Ghana. Telecommun. Policy 2011, 35, 494-504. [CrossRef]

20. Fuchs, C.; Horak, E. Africa and the digital divide. Telemat. Inform. 2008, 25, 99-116. [CrossRef]

21. Birba, O.; Diagne, A. Determinants of adoption of Internet in Africa: Case of 17 sub-Saharan countries. Struct. Chang. Econ. Dyn. 2012, 23, 463-472. [CrossRef]

22. Penard, T.; Poussing, N.; Mukoko, B.; Piaptie, G.B.T. Internet adoption and usage patterns in Africa: Evidence from Cameroon. Technol. Soc. 2015, 42, 71-80. [CrossRef]

23. James, J. Mobile phones and safety in developing countries: Evidence from Sub-Saharan Africa. Geoforum 2015, 62, 47-50. [CrossRef]

24. Howard, P.N.; Mazaheri, N. Telecommunications reform, Internet use and mobile phone adoption in the developing world. World Dev. 2009, 37, 1159-1169. [CrossRef]

25. Groupe Speciale Mobile Association (GSMA). The Mobile Economy. In Sub-Saharan Africa; Technical Report; GSMA Intelligence: London, UK, 2014; p. 78.

26. Muto, M.; Yamano, T. The impact of mobile phone coverage expansion on market participation: Panel data evidence from Uganda. World Dev. 2009, 37, 1887-1896. [CrossRef]

27. Overa, R. Networks, distance, and trust: Telecommunications development and changing trading practices in Ghana. World Dev. 2006, 34, 1301-1315. [CrossRef]

28. Buys, P.; Dasgupta, S.; Thomas, T.S.; Wheeler, D. Determinants of a digital divide in Sub-Saharan Africa: A spatial econometric analysis of cell phone coverage. World Dev. 2009, 37, 1494-1505. [CrossRef]

29. Adams, E.A.; Zulu, L.C. Participants or customers in water governance? Community-public partnerships for peri-urban water supply. Geoforum 2015, 65, 112-124. [CrossRef]

30. Wakeyo, M.B.; Gardebroek, C. Empty pockets, empty ponds? Disadoption of water harvesting technologies in Ethiopia. J. Arid Environ. 2015, 120, 75-86. [CrossRef]

31. Mponela, P.; Tamene, L.; Ndengu, G.; Magreta, R.; Kihara, J.; Mango, N. Determinants of integrated soil fertility management technologies adoption by smallholder farmers in the Chinyanja Triangle of Southern Africa. Land Use Policy 2016, 59, 38-48. [CrossRef]

32. Schnegg, M.; Bollig, M. Institutions put to the test: Community-based water management in Namibia during a drought. J. Arid. Environ. 2016, 124, 62-71. [CrossRef]

33. Swan, A.; Cooper, N. Innovative funding methods for rural communities and their water pumps. Water Resour. Rural Dev. 2013, 1-2, 17-26. [CrossRef]

34. García-Castro, N.; García-Rincón, J. Evaluación de la Situación Sanitaria en Beleko, Mali, y Propuestas Contra la Contaminación Microbiológica. Master's Thesis, Universidad de Alcalá, Madrid, Spain, 2017. (In Spanish)

35. Anell, A.; Willis, M. International comparison of health care systems using resource profiles. Bull. World Health Organ. 2000, 78, 770-778. [PubMed]

36. Jaramillo, C.; Lizárraga, C.; Grindlay, A.L. Spatial disparity in transport social needs and public transport provision in Santiago de Cali (Colombia). J. Transp. Geogr. 2012, 24, 340-357. [CrossRef] 
37. Wang, C.H.; Chen, N. A GIS-based spatial statistical approach to modeling job accessibility by transportation mode: Case study of Columbus, Ohio. J. Transp. Geogr. 2015, 45, 1-11. [CrossRef]

38. Schuurman, N.; Amram, O.; Crooks, V.A.; Johnston, R.; Williams, A. A comparative analysis of potential spatio-temporal access to palliative care services in two Canadian provinces. BMC Health Serv. Res. 2015, 17, 270. [CrossRef] [PubMed]

39. Ursulica, T.E. The relationship between health care needs and accessibility to health care services in Botosani County-Romania. Procedia Environ. Sci. 2016, 32, 300-310. [CrossRef]

40. Aldasouqi, I.; Salameh, W.A. Using GIS in designing and deploying wireless network in city plans. Int. J. Comput. Netw. 2014, 6, 66-75.

41. Nayan, N.; Hashim, M.; Saleh, Y.; Mahat, H. Mapping internet coverage in Malaysia's university campuses: A case study of the Sultan Idris Education University, Perak. Malays. J. Soc. Space 2016, 12, 118-125.

42. Dhanasekarapandian, M.; Chandran, S.; Saranya Devi, D.; Kumar, V. Spatial and temporal variation of groundwater quality and its suitability for irrigation and drinking purpose using GIS and WQI in an urban fringe. J. Afr. Earth Sci. 2016, 124, 270-288. [CrossRef]

43. Toure, N.M.; Kane, A.; Noel, J.F.; Turmine, V.; Nedeff, V.; Lazar, G. Water-poverty relationships in the coastal town of Mbour (Senegal): Relevance of GIS for decision support. Int. J. Appl. Earth Obs. Geoinf. 2012, 14, 33-39. [CrossRef]

44. Wright, J.; Liu, J.; Bain, R.; Perez, A.; Crocker, J.; Bartram, J.; Gundry, S. Water quality laboratories in Colombia: A GIS-based study of urban and rural accessibility. Sci. Total Environ. 2014, 485-486, 643-652. [CrossRef] [PubMed]

45. United Nations International Children's Emergency Fund. The rights to safe water and to sanitation. UNICEF Curr. Issues 2014, 3, 1-5.

46. World Health Organization-UNICEF. Progress on Drinking Water and Sanitation: 2012 Update; UNICEF and World Health Organization: Geneva, Switzerland, 2015; p. 66. ISBN 978-92-806-4632-0.

47. OXFAM. Oxfam delagua portable water testing kit. In User Manual; University of Surrey: Guildford, UK, 2009; p. 65.

48. Paruch, A.M.; Mæhlum, T. Specific features of Escherichia coli that distinguish it from coliform and thermotolerant coliform bacteria and define it as the most accurate indicator of faecal contamination in the environment. Ecol. Indic. 2012, 23, 140-142. [CrossRef]

49. Hathaway, J.M.; Krometis, L.H.; Hunt, W.F. Exploring seasonality in E. coli/fecal coliform ratios in urban watersheds. J. Irrig. Drain. Eng. 2014, 140, 04014003. [CrossRef]

50. Sphere Project. Humanitarian Charter and Minimum Standards in Humanitarian Response; The Sphere Project: Rugby, UK, 2011; ISBN 978-1-908176-00-4.

51. World Health Organization. Guidelines for Drinking-Water Quality; Technical Report; World Health Organization: Geneva, Switzerland, 2011; p. 541. ISBN 978-92-4-154815-1.

52. Hachich, E.M.; Di Bari, M.; Christ, A.P.G.; Lamparelli, C.C.; Ramos, S.S.; Sato, M.I.Z. Comparison of thermotolerant coliforms and Escherichia coli densities in freshwater bodies. Braz. J. Microbiol. 2012, 43, 675-681. [CrossRef] [PubMed]

53. World Health Organization. Environmental Health in Emergencies and Disasters: A Practical Guide; World Health Organization: Geneva, Switzerland, 2002; p. 252. ISBN 92-4-154541-0.

54. SASPlanet Software, Version 141212.8406; SASPlanet Development Team. Available online: www.sasgis.org (accessed on 25 May 2017).

55. United Nations Office for the Coordination of Humanitarian Affairs. Mali-Humanitarian Data Exchange. Available online: https:/ / data.humdata.org/group/mli (accessed on 25 May 2017).

56. Obeng-Odoom, F. Beyond access to water. Dev. Pract. 2012, 22, 1135-1146. [CrossRef]

57. Smiley, S.L. Complexities of water access in Dar es Salaam, Tanzania. Appl. Geogr. 2013, 41, $132-138$. [CrossRef]

58. Jones, S.D. Sharing the Recurrent Costs of Rural Water Supply in Mali: The Role of WaterAid in Promoting Sustainable Service Delivery. Ph.D. Thesis, University of London, London, UK, 2013.

59. Kumpel, E.; Nelson, K.L. Intermittent water supply: Prevalence, practice, and microbial water quality. Environ. Sci. Technol. 2016, 50, 542-553. [CrossRef] [PubMed]

60. Gulliford, M.; Figueroa-Munoz, J.; Morgan, M.; Hughes, D.; Gibson, B.; Beech, R.; Hudson, M. What does "access to health care" mean? J. Health Serv. Res. Policy 2002, 7, 186-188. [CrossRef] [PubMed] 
61. Mwamaso, A.A. Measuring and Mapping Citizens' Access to Rural Water Supply in Tanzania. Master's Thesis, University of Twente, Enschede, The Netherlands, February 2015.

62. Nganyanyuka, K.; Martinez, J.; Wesselink, A.; Lungo, J.H.; Georgiadou, Y. Accessing water services in Dar es Salaam: Are we counting what counts? Habitat Int. 2014, 44, 358-366. [CrossRef]

63. Xu, K.; Saksena, P.; Evans, D.B. Health Financing and Access to Effective Interventions; World Health Report (2010), Background Paper, No. 8; World Health Organization: Geneva, Switzerland, 2010; p. 18.

64. Bartram, J. Improving on haves and have-nots. Nature 2008, 452, 283-284. [CrossRef] [PubMed]

65. Heitzinger, K.; Rocha, C.A.; Quick, R.E.; Montano, S.M.; Tilley, D.H., Jr.; Mock, C.N.; Carrasco, A.J.; Cabrera, R.M.; Hawes, S.E. "Improved” but not necessarily safe: An assessment of fecal contamination of household drinking water in rural Peru. Am. J. Trop. Med. Hyg. 2015, 93, 501-508. [CrossRef] [PubMed]

66. Onda, K.; LoBuglio, J.; Bartram, J. Global access to safe water: Accounting for water quality and the resulting impact on MDG progress. Int. J. Environ. Res. Public Health 2012, 9, 880-894. [CrossRef] [PubMed]

67. Shaheed, A.; Orgill, J.; Montgomery, M.A.; Jeuland, M.A.; Brown, J. Why "improved" water sources are not always safe. Bull. World Health Organ. 2014, 92, 283-289. [CrossRef] [PubMed]

68. Gundry, S.W.; Wright, J.A.; Conroy, R.; duPreez, M.; Genthe, B.; Moyo, S.; Mutisi, C.; Ndamba, J.; Potgieter, N. Contamination of drinking water between source and point-of-use in rural households of South Africa and Zimbabwe: Implications for monitoring the Millennium Development Goal for water. Water Pract. Technol. 2006. [CrossRef]

69. Onabolu, B.; Jimoh, O.D.; Igboro, S.B.; Sridhar, M.K.C.; Onyilo, G.; Gege, A.; Ilya, R. Source to point of use drinking water changes and knowledge, attitude and practices in Katsina State, Northern Nigeria. Phys. Chem. Earth Parts A/B/C 2011, 36, 1189-1196. [CrossRef]

70. Hutchings, P.; Parker, A.; Jeffrey, P. The political risks of technological determinism in rural water supply: A case study from Bihar, India. J. Rural Stud. 2016, 45, 252-259. [CrossRef]

71. Zawahri, N.; Sowers, J.; Weinthal, E. The politics of assessment: Water and sanitation MDGs in the Middle East. Dev. Chang. 2011, 42, 1153-1177. [CrossRef]

72. Bain, R.; Cronk, R.; Wright, J.; Yang, H.; Slaymaker, T.; Bartram, J. Fecal contamination of drinking-water in low- and middle-income countries: A systematic review and meta-analysis. PLoS Med. 2014, 11, e1001644. [CrossRef] [PubMed]

73. Bain, R.E.S.; Wright, J.A.; Christenson, E.; Bartram, J.K. Rural: Urban inequalities in post 2015 targets and indicators for drinking water. Sci. Total Environ. 2014, 490, 509-513. [CrossRef] [PubMed]

74. Foster, T.; Hope, R. A multi-decadal and social-ecological systems analysis of community waterpoint payment behaviours in rural Kenya. J. Rural Stud. 2016, 47, 85-96. [CrossRef]

75. Lutz, A.; Thomas, J.M.; Diarra, S. Chemistry of hand-pump waters in Ghana, Mali, and Niger, West Africa: Potential health effects. Procedia Earth Planet. Sci. 2013, 7, 541-545. [CrossRef]

76. James, J. Which developing countries have done the most to close the digital divide? Telemat. Inform. 2012, 29, 2-10. [CrossRef]

77. James, J. Sharing mobile phones in developing countries: Implications for the digital divide. Technol. Forecast. Soc. Chang. 2011, 78, 729-735. [CrossRef]

78. Van Dijk, J.; Hacker, K. The digital divide as a complex, dynamic phenomenon. Inf. Soc. 2003, 19, 315-326. [CrossRef]

79. Porter, G. Living in a walking world: Rural mobility and social equity issues in Sub-Saharan Africa. World Dev. 2002, 30, 285-300. [CrossRef]

80. Pritchett, L.; Woolcock, M. Solutions when the Solution is the Problem: Arraying the disarray in development. World Dev. 2004, 32, 191-212. [CrossRef]

(C) 2017 by the authors. Licensee MDPI, Basel, Switzerland. This article is an open access article distributed under the terms and conditions of the Creative Commons Attribution (CC BY) license (http:/ / creativecommons.org/licenses/by/4.0/). 